\title{
The pig story "tiboi sakkoko" Storytelling of kinship, memories of the past, and rights
to plots of ancestral land in Mentawai
}

\author{
JUNIATOR TULIUS
}

\begin{abstract}
This paper examines some significant elements of the pig story (tiboi sakkoko). This tale contains crucial information about the collective identity, ancestors and historical events affecting particular Mentawai kin-groups. As families do not preserve their culture and traditions in written form, storytellers of kin-groups have narrated the pig story from generation to generation so as to preserve it carefully. In the course of time, storytellers establish particular ways of telling their stories so as to remember the content and plot of the stories easily. Through the pig story, members of kin groups also recollect their ancestral place of origin and plots of ancestral lands. The role of human memory is indispensable to recalling all these important elements. Therefore, this paper analyses memories of the past of different family generations. To achieve its aims, this paper also evaluates the roles of family stories in the culture and traditions of Mentawai society.
\end{abstract}

KEYWORDS

Mentawai; oral tradition; family story; memory; ancestor; ancestral migration; and ancestral land.

\section{INTRODUCTION}

In the twentyfirst century, Mentawaians and migrants from other places in Indonesia are seizing the new opportunities offered by the current developments in the islands. Tourism, the construction of better infrastructure and appointments as government officials all offer chances of employment for those looking for a better economic future. All of these people need sites on which to build new houses and open new gardens. To meet the demand the local government is planning to extend villages and open new branches of the economy. Hopefuls go in search of and buy plots of land, but this process is not all as easy as water off a duck's back. Land in Mentawai presents a minefield

\footnotetext{
JUNIATOR TULIUS completed his doctorate in anthropology from the Leiden University Institute for Area Studies at Leiden University. He is currently a research fellow at Earth Observatory of Singapore, an institute of Nanyang Technological University in Singapore. Juniator Tulius may be contacted at: tjuniator@ntu.edu.sg and juniator.tulius@yahoo.com.
}

(C) 2016 Faculty of Humanities, University of Indonesia

JUNIATOR TULIUS | DOI: 10.17510/wacana.v17i2.450 
of complicated problems. Landowners do not have written documents to prove their actual claim to the land and it is not unheard of that they actually attempt to sell other people's land to buyers.

This is just one situation presenting problems involving different people in conflicts over land rights. If it is to develop the region, the District Government of the Mentawai Archipelago needs access to land in Mentawai. The provincial government situated in Padang and the central government located in Jakarta have allocated areas in Mentawai for different purposes (Darmanto and Setyowati 2013; Persoon 2003). Most omit of decisions made for managing the natural resources in Mentawai are made without bothering to ask the consent of the Mentawain people as the indigenous owners of the land by right of their culture and custom as the indigenous people of the Mentawai Islands. Most of the areas assigned by the governments in the Mentawai Islands have been set aside for large-scale logging concessions, large conservation areas as well as some plans for extensive oil palm plantations in particular localities. These large-scale plans leave relatively small areas allocated for traditional land uses. Any policy which would affirm the accumulated rights of indigenous Mentawai people to their ancestral land are more honoured in the breach than the observance. Therefore, Mentawai people currently feel threatened by the potential loss of their rights to plots of ancestral land as a consequence of the decisions made above their heads by the provincial and central governments. The district government seems incapable of mediating the aspirations of the Mentawai people in their efforts to gain their rights to their ancestral land. These governments decide unilaterally what is to happen on their ancestral land and territories in Mentawai Islands.

In a concerted effort to maintain their rights to their ancestral land, the Mentawai people have been fighting to recollect stories to do with their land which might allow them to define and reclaim their land. The process is not simple as Mentawai society consists of 200 different kin group names. Each kin group has tens of extended families and each of the kin groups has a family story recounting that kin group's historical particulars. Each story has a title so that it is easily remembered by its members. Pertinently, the title of a family story is frequently used to distinguish one kin group from another. A typical story contains the kin-group's origins, its connections with other kin groups and an enumeration of the plots of ancestral land which belong to that particular kin group. As some groups share the same ancestral connections, they also share the same collective identity. Therefore, a family story recounts the ancestral connections between several different present-day Mentawai kin groups which share the same ancestors who found and claimed all the plots of land in particular places in the Mentawai Islands before Mentawai was proclaimed part of the Indonesian unitary state soon after this was founded in 1945. Taking note of this situation, I have addressed a number of relevant questions in this paper, namely: How does a family story connect one kin group to one another? What kinds of collective particulars does a family story reveal about these linked kin groups? How does the family story preserve 
historical family particulars? In short, what is the significance of family stories mean for Mentawai kin groups?

This paper is composed of a brief literature discussion about storytelling in an oral tradition, the transmission of oral messages and the preservation of memories of the past. An explanation of Mentawai oral tradition is omitted as it has been discussed elsewhere (see Tulius 2012a, 2014). The genre of oral tradition chosen to be discussed in this paper is the family story, in particular the pig story (tiboi sakkokok). It is part of tiboi genre of Mentawai oral tradition, also known as tiboi tubu (a oneself story) or tiboi teteu (an ancestors' story). This type of story has strong links to tiboi polak (land stories), tiboi leleu (forest stories), and tiboi mone (garden stories) (Tulius 2012b). Two selected pig stories are introduced in order to abstract elements and characteristics of the family story. The stories were gathered from Mentawaians of the Samongilailai kin groups residing in different places in the Mentawai Islands.

\section{MENTAWAI ISLANDS AND THE MENTAWAIANS}

Mentawai is the name of an ethnic group and a group of islands situated off the western coast of Sumatra in Indonesia. Until 4 October 1999, the Mentawai Islands (see Picture 1) were part of the Sumatran mainland district of Padang Pariaman. Under Indonesian Law number 49/1999, it is now recognized as an independent district called Pemerintahan Kabupaten Kepulauan Mentawai (District Government of the Mentawai Archipelago) by the central government of Indonesia. The local district government of the Mentawai Archipelago has been attempting to speed up regional developments by providing better infrastructure, including roads and marine transportation and improving other governmental facilities such as schools, medical centres and so on. Its efforts is to fulfil the Mentawai people's request for more progressive development after the district government of Padang Pariaman had dragged its heels in the development of the region for years after Mentawai had become part of Indonesia in 1945. Indifferent to introducing progress, the district government of Padang Pariaman eagerly exploited the region. Different organizations were encouraged to make a contribution to finding better approaches to handling the Mentawai region (see Persoon and Schefold 1985).

In 2002 there were 65,765 people living in Mentawai (Tulius 2012a: 52). According to unpublished data from the Department of Population and Civil Registration of the District Government of Mentawai Archipelago in 2014, at present 88,000 people are living there. Migrant numbers are low, the majority being civil servants and merchants from Sumatra and other places in Indonesia. The total population has increased quite significantly in the last decade because of better formal education and healthcare services. Child mortality has dropped significantly as public health services and other health programmes run by the local government and non-governmental organizations have run active health education programmes and promoted a healthy life-style. This small archipelago consists of four inhabited islands, Siberut, Sipora, and North and South Pagai, complemented by scores of small islets. Officially 
uninhabited, these islets are used for coconut gardens and temporary shelter for fishermen. As a complete archipelago Mentawai has a total landmass of $6,011.35$ square kilometres. The indigenous Mentawai people make up about 80 per cent of the total population. The archipelago is located about 100 miles off the shores of the province of West Sumatra.

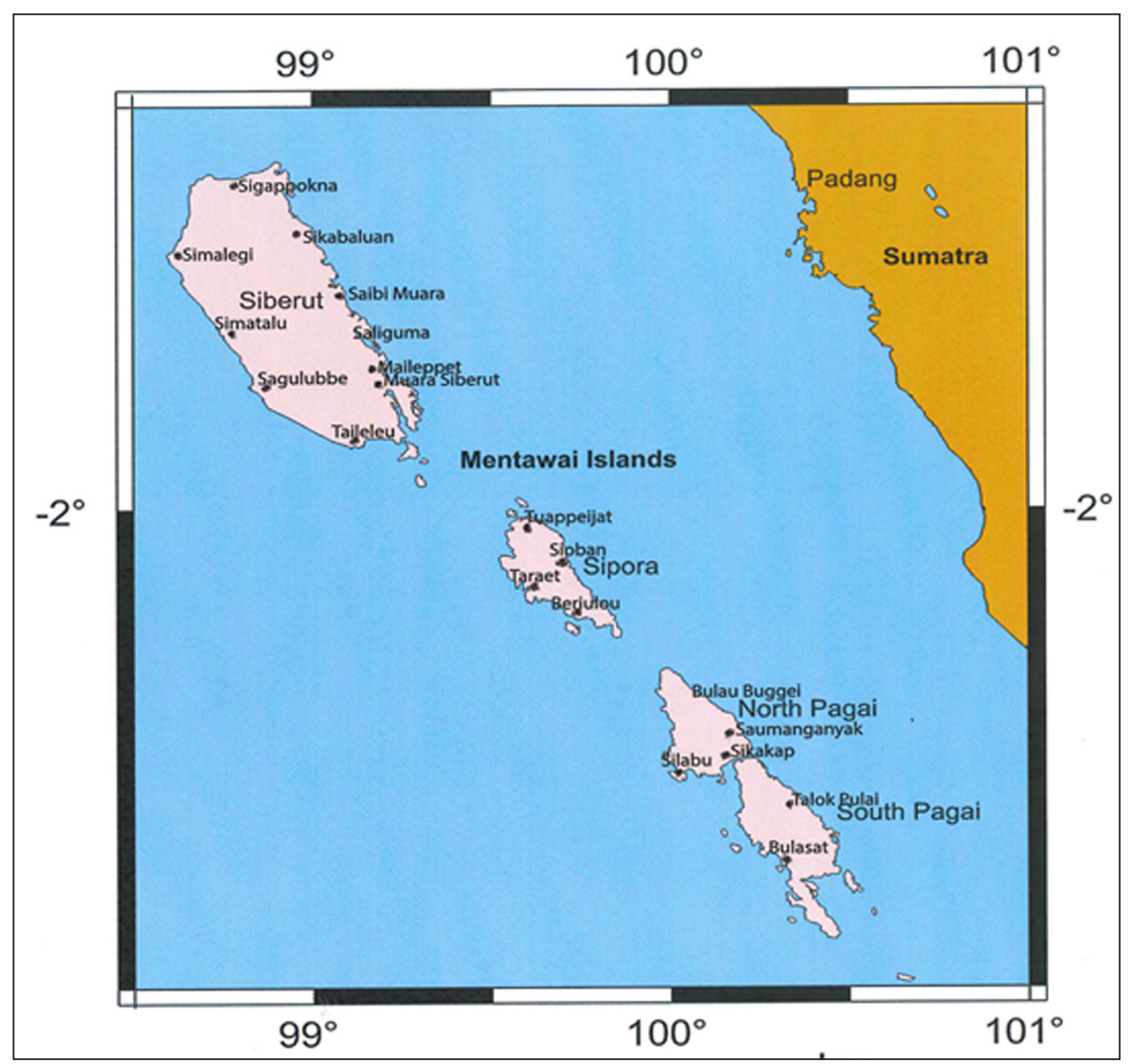

Picture 1. Mentawai Islands. The original map is taken from https://commons. wikimedia.org /wiki/File:Mentawai_Islands_Map.png accessed in October 2015, and it has been adjusted by the author by adding several local names to suit the requirements of this paper.

\section{METHODOLOGY}

Sipora, situated between Siberut and the two Pagai Islands, was an ideal place to begin fieldwork as well as to assess Mentawaians' memory of the past and find out whether Mentawaians would remember or forget their origins in the course of data gathering by interview. Despite having particular, slightly different traditional customs, the populations of the southern Mentawai islands of Sipora and Pagai share common generic cultural characteristics with those who live in Siberut (Schefold 1988, 1991; Nooy-Palm 1968; Loeb 1928). My expectation was that kin groups in Sipora would inform me about their ancestors and the location of their ancestral lands. Proceeding on the 
basis of the information gathered on Sipora, I selected several kin groups and attempted to reconstruct the family relationships which might exist among them. I asked members of the kin groups I had selected to advise me on which individuals or storytellers I should get in touch with to obtain information about their ancestors' migratory movements.

The selected stories presented in this paper are derived from my $\mathrm{PhD}$ thesis (Tulius 2012a), and were gathered during fieldwork and a series of interview with elderly members of different Mentawai kin groups who I visited in their villages. Methodologically, I followed suggestions discussed by Bernard (1994) and Briggs (1986) by interviewing different people and consulting members of kin groups to obtain information about storytellers who would be able to tell me their family stories during fieldwork. Acting on information gathered from the stories and suggestions made by the storytellers, I met other storytellers and recorded their stories. Data consisting of family stories were transcribed into story texts in the Mentawai language and translated and adjusted to English texts. The story texts are presented in this paper according to the chronological order in which I collected them. The information given in the stories is still relevant to the current issues discussed in this paper. Therefore, I have decided to re-use it to illustrate how a kin group expands into several kin-groups and how stories collected within the same kin group differ from one another.

\section{ORAL TRADITION AND STORYTELLING}

In Indonesia oral tradition or tradisi lisan is a common, major form of preserving information about general cultural values and the specific norms and customs observed by particular Indonesian societies. In short, oral tradition is a major cultural form among Indonesian peoples. Jan Vansina, a leading scholar on the subject of oral tradition, studied the oral traditions of communities in several parts of the globe. On the basis of the results of his research, Vansina states, "Oral traditions are historical sources of a special nature. Their special nature derives from the fact that they are "unwritten" sources couched in a form suitable for oral transmission, and that their preservation depends on the powers of memory of successive generations of human beings" (Vansina 1973: 1). He mentions three main elements of oral tradition. The first is that oral tradition recounts historical events. The second is that it is verbally transmitted through the generations of a family. To ensure the efficacy of this process, a storyteller needs to compose his story structurally and formulate it simply before he transmits it verbally to his audience. His actions embody the concept of verbal formulations, performances and events which resembles the descriptions of oral performance recorded by Bauman (1986). The process involves particular gestures, changes in tone and the mimicry by the storyteller. The third point Vansina makes is that oral tradition relies on the power of human memory to preserve the historical events. The sustainability of oral significance is important in preserving information about past events, making them available in the present. Therefore it does indeed rely on the memories 
of certain individuals (leaders of groups) and particular groups of people (several elders of groups or of a community). This selection of individuals makes it patently clear that members of the family, kin group or community realize that not all elderly members are capable of bearing this responsibility. Among the mature members are only a few individuals who are gifted with a real talent for giving leadership to the rest of the family and being granted the opportunity to declaim their family stories. As a rule these gifted people are drawn from among the elderly members of the kin group.

To guide them in their remembrance of the contents of a family story, storytellers can rely on certain rules and methods to guide them in their proper recounting of their family's story. They must choose particular occasions on which to tell the stories. Certain elders are selected to assume the important role of the prominent storyteller of their family. These elders preserve their family stories carefully and therefore succeed in transmitting the essential content of the stories accurately down through the generations, concentrating especially on those who are perceived by the elders to have a certain quality and talent for speaking, listening and memorizing what they have heard. For a kin group it is crucial to preserve the stories as accurately and completely as possible, because they realize that family stories establish the identity of the kin group. Mature leaders must have a good memory to remember the details of past events. Very importantly they must have a particular talent for telling the stories in such a way that other family members can readily understand the content. The elderly members of a family or kin group are gifted with the capacity to remember the common familial past in their own manner and to pass the memory on to their family or kin group. Members of a family or kin group can easily recognize the themes in a story about particular events which have affected their family or community. By following this pattern, the most important themes of the story of an event are preserved and transmitted to following generations. Taking note of this situation, one of the eleven proposition which supplemented my PhD thesis was: "In oral tradition, memorizing past events that once affected a family, kin group or community, is powerful tool in the establishment of a fundamental understanding of the connections between these past events and current circumstances" (Tulius 2012a).

Local people need a method to preserve their ancient traditions and scholars also require guidelines to understand stories properly and collect them correctly for their research. In order to study the three major elements mentioned by Vansina, I have found the work of some scholars like Bruner (1986) and Finnegan (1992) very helpful. They remind us as oral tradition researchers to pay attention to some particular approaches and perspectives. The approach I find personally most interesting in studying oral tradition is the perspective of the local people on how they perceive their particular circumstances. This is also used by Basso (1996) to appraise the local situation. He discovered that the Western Apache people of Cibecue have different narratives, each of which has a different historical significance and therefore 
they have a collection of diverse "historical tales". By applying different terms to define different narratives in an oral tradition, Basso tries to understand the life of the local people by referring to the local people's perspective in seeing themselves through the context of his research and the place in which they live (see also other examples in Sense of place edited by Feld and Basso 1996). Basso (1996: 48) has followed the classification made by the Apache people, with the intention of getting closer to an interpretation of native claims about the symbolic importance of geographical features and the personalized relationships which individuals might have with them. An important native claim has to do with events which occurred in the past but have been of such significance to them to have become part of their "history". The medium used to preserve such information is called a "historical tale"". As some historical tales concern a particular family, they are defined as "family historical tales" and their discourse is about the history of a particular family.

As oral tradition speaks about the importance of memories of the past, Thompson (2000) assumes that scholars cannot fail to take notice of the fact that storytellers have particular ways of maintaining their oral tradition. For example, they keep remembering key words. Storytelling, also known as the performance-in-telling of a story or the act of narrating, is an element of oral tradition (Finnegan 1992). The length of stories depends on such factors as a storyteller's memory and knowledge of events, both necessarily limited. Importantly a storyteller does not remember details of an event. Instead, he recounts his impression of an event which he once heard about his ancestors. Importantly, even though he might remember it clearly, a storyteller might not want to tell his ancestral story in detail because he is keen to prevent the details spreading outside the family circle. The current generation attempts to memorize what has been heard or learned from the previous generation. The nature of human memory plays a crucial role in the preservation of these historical matters. After familiarizing themselves with different elements, themes and motifs of family stories, family members usually communicate with each other in order to avoid any misunderstandings and conflicts with other kin groups.

\section{MEMORIES OF THE PAST IN ORAL TRADITION}

Memory plays an important role in preserving the past events described in oral tradition. The interconnections of memory, cognition and past events help us to understand about ourselves. Language allows us to reconstruct our past and storytelling allows us to be familiar with the past events at every moment. This brings me to the research of Mary Margaret Steedly (1993) among Batak Karo communities in North Sumatra. To quote Steedly:

Memory is never private property and experience is never a simple matter in this overinhabited terrain; voices are always multiple, fragmented, interrupted, possessed by the memories of other people's experience. The transfer and transcription of historical experience - in names, monuments, genealogies; in collective fantasy and in the regulated social intercourse of everyday life; in law, 
property, and desire; in stories inhaled with the common air of a shared place or time - is the moment through which subjectivity is produced (Steedly 1993: 22).

In short, the memories of human beings are collective and social, delimited by particular groups of people, spaces, places and times. In relation to the notion of memory conceived by Steedly, I came across the work of Maurice Halbwachs who in 1952 wrote an important study of memory under the title of Les cadres sociaux de la mémoire. ${ }^{1}$ Halbwachs (1992: 53) calls this "the framework of collective memory", which confines and binds our most intimate remembrances to each other. Furthermore, Halbwachs writes "The collective framework of memory is the result or sum or combination of individual recollections of many members of the same society" Therefore, as Coser writes, "[collective] memory needs continuous feeding from collective sources and is sustained by social and moral props" (Coser 1992: 34). Collective memory manifests itself in the traditions of families and different social groups.

When speaking of memory and oral tradition, most people do try to remember the important events of their past. Davis and Starn state that, "one's memory of any given situation is multiform and that its many forms are situated in place and time from the perspective of the present" (1989: 2). People refer to particular places and moments which might remind them of certain occurrences and they convey those matters in storytelling. Davis and Starn (1989:5) note that people remember events which occurred in the recent past and were personally experienced by themselves, as well as events in the "old past", which were experienced by their ancestors. I see this as historical representations in places and time through the power of recollecting the past experience of different family generations. On this account, I also agree with Fentress and Wickham (1992) that family stories are mnemonic devices for bringing past events to the present. Family stories represent the high potential of the human consciousness of past events. This is one of the characteristics of stories: to manifest the cognitive functions of human beings (Rubin 1995: 302-303).

Cultural objects are not to be categorized as part of oral tradition. However, in several cases found among different ethnic groups in the world, many objects do serve to remind people of something. Certainly, particular objects are made for particular events in Mentawai and elsewhere in Indonesia and these events and objects have their stories. Communal objects are important to a community because objects refresh people's memory of particular past events. Objects and events become arranged in people's thoughts in order to remind them about the chronological order of events and the names and meanings of the objects themselves and the events, all of which have contributed to their identity. Therefore, stories of particular objects are told in particular family stories.

Hoskins (1998: 9) notes that objects can be invested with great significance in both the collective representation of the past and the individual storing of 
biographical memory. Cultural objects are mnemonic devices. Hoskins (1998: 3) states that particular objects might clearly reveal which kin groups are perceived as sharing the same relationship ancestrally and which kin groups are perceived as "other". In a nutshell, cultural objects might help people to remember their relatives. Past occurrences can be materialized in the present in the form of historical accounts, cultural objects and storytelling.

Instead of remembering, Carsten (1995: 318, 329-330) and H. Geertz and C. Geertz (1964) look at several cases of certain Southeast Asian peoples who have been represented as afflicted by "structural amnesia" or "genealogical amnesia", forgetting who their ancestors were. This lapse illustrates that human memory can be deficient in preserving all significant details of past occurrences. In Mentawai, I have observed that "genealogical amnesia" is a major factor in conflicts over land. "Amnesia" refers to the phenomenon of crucial information fading from people's memory. People can forget important things and in Mentawai such lapses sometimes happen naturally and are sometimes caused by political expediency.

Referring to the Malaysian island of Langkawi, Carsten (1995: 319) writes that people from other parts of Southeast Asia had come to Langkawi for a variety of reasons. They currently affirm themselves as Langkawi people, instead of seeing themselves as coming from Sumatra, Singapore or Malaysia. Carsten states that, in order to be acknowledged politically as Langkawi inhabitants, the new generations of migrants on Langkawi have lost interest in maintaining their initial origin. Consequently, "there is no systematic attempt to maintain tradition or memories of ancestors who have come from elsewhere" (Carsten 1995: 320). In this case, they have not only created kinship in a social and political context, but also established a newly created shared identity (Carsten 1995: 318, 329-330; see also H. Geertz and C. Geertz 1964 for a Balinese context of "genealogical amnesia").

Taking an example from Mentawai to do with the remembering or forgetting of someone's name reveals that details of someone's memory are strongly influenced by tradition. In Mentawai, someone's name might change frequently as he or she passes through particular stages of social life. It begins when a baby is born. A baby girl is called sijijik and a baby boy is called sikolik. Then, at a certain age, she or he is given a "real" name in a ritual. The name becomes an identity of the person, for instance, Emeiboblo in the pig story which I present later in this paper. Soon after Emeiboblo was married and had a baby, he needed to find a name for his child, Kora for instance. Thereafter, his child's name would be his teknonym. Henceforth he would be called Aman Kora (father [ama] of Kora). As he grew older, Emeiboblo would be called teteu, or teu for short, meaning 'grandfather'. This term is added in front of his current name. So he was called Teteu or Teu Emeiboblo. After Emeiboblo had passed away, he would be addressed with the word kalimeu (deceased or late) before his name, Kalimeu Emeiboblo. In traditional rituals, Emeiboblo's spirit is categorized as ukkui (ancestor's spirit). In the spiritual world he is perceived as living with other spirits, and they are called sanitu 
(see Schefold 1973 for further discussion of religious concepts in Mentawai). When there are so many situational changes of a personal name and identity, recognizing someone's name becomes complicated.

After someone's death, in Mentawai traditional culture that person's name is mentioned infrequently because people do not want to relive images and memories of the dead. Mentawaians believe that dead relatives have gone to live in the other world, the spiritual world. The spiritual world is interpreted as an invisible 'big village' (beu laggai). The ancestors are not supposed to be disturbed unless they are called upon to be present at family gatherings, for instance, for rituals. In order not to mention someone who has died, relatives of the deceased use other words to refer to the dead person. Sapunuteteu is a common term used in family stories as the term for ancestors, and kalimeu is the term for those more recently deceased. In rituals, the ancestors are called ukkui.

From the Mentawai people's point of view, dead people always live in the vicinity of living people but are invisible. Emphatically, they should not be present in the world of the living. If living people mention a dead person's name again and again, eventually the spirit of the dead might appear to them as an apparition. When the appearance of a spirit of a dead person occurs under ordinary circumstances, many family members might fall ill. To ensure the protection of family members holding a ritual, shamans bless them. Once this has been done, the spirits of ancestors and living people can be present at the same ritual without knowing of each other's presence. To show respect to the ancestors, their names are not mentioned, but should this be unavoidable, Mentawaians deliberately hide their ancestors' names.

The forgetting of ancestors can also be an outcome of particular customs. Some individual names of ancestors in Mentawai are deliberately obscured, as some particular cases of headhunting raids involving the family's ancestors are still open. In fact, some kin groups whose ancestors were victims of headhunting raids still retain the memory of these events, even though the headhunting tradition ended several generations ago. Someday in the future, these families will ask the kin groups which killed their ancestors for payment (compensation) for the deaths. Such information must continue to be transmitted through the generations. When the link between generations is missing and messages are no longer conveyed, the ancestors' name might indeed be forgotten.

However, the question is how far the communities are able to reduce the memory of their past if they have a strong connection to their ancestors and ancestral culture. With reference to the Rotinese, Fox (1980: 65) states, "By reducing the memory of the past events to the merest anecdote, a rich oral tradition is able to embellish ancestral action in accordance with the needs of members of kin groups that suit present circumstances." In order to explain this phenomenon, I follow the idea of Halbwachs (1992: 172) that forgetting almost always results from a distraction, which is often explained by the disappearance of frameworks of memory or a part of them, either because 
people's attention is no longer able to focus on them or because it is focused somewhere else. In other words, the issue of forgetting is political.

People's memory cannot retain all the details of past occurrences. For example, the precise location of far-away plots of land and their boundaries are often recollected incompletely. The group currently using the land (while not owning the land) frequently claims ownership of the land or claims exaggerated boundaries for their land. Halbwachs (1992) has noted that the forgetting or deformation of certain recollections is explained by the fact that the frameworks of memory change from one period to another in order to meet the different needs of communities.

\section{THE DOMESTICATION OF THE PIG IN MENTAWAI CULTURE}

As the stories I relate involve pigs, a word or two about the importance of pigs in Mentawai culture is in order. Mentawaians traditionally raise pigs. Having pigs benefits the whole family. Every family member is involved in taking care of the pigs, as the animals need to be tended every day. Adult men chop down the trunks of the sago palm growing near their homestead and cut them into several small logs. They soak these logs in the river in order to maintain the quality of the soft part of the sago and to prevent the log rotting. These logs float in the water close to the riverbank. Women and young people go to the riverbank to take a sago log whenever they need to feed their pigs. They divide up the log into smaller portions so that the pigs can easily eat the soft pith of the sago. As it is not an easy task to raise pigs, the Mentawaians do not simply slaughter their pigs. Nevertheless, they sometimes do eat pork on ordinary days, for instance, if no meat has been obtained from hunting wild animals and they slaughter their pigs for various rituals: those held for a newly born baby, a wedding, for a new house, for healing and a few other minor rituals.

Mentawai houses are built on strong wooden stilts. Under the house floor there is enough space to keep several pigs. Mentawai people sometimes fence in a pen under their house so that they can keep a close watch on their animals. Alternatively, people might build a roofed pig-pen alongside their house, or near their garden by a riverbank. Pigs are not completely domesticated. They are free to roam around in the vicinity of people's houses during daylight in order to forage for something to eat but return to the pen, where family members feed them sago palm in the evening.

Before a family begins raising pigs, the father of the family usually carries out a small ritual to protect the pigs from a number of dangers: being eaten by snakes, being stolen by other people and from illnesses which can wipe out all the pigs in one fell swoop. Prior to carrying out the ritual, the father has to observe a number of taboos, such as not eating uncooked foods and not having sexual relations for a period of time, usually three or four weeks. During the ritual, the father marks the new pigs (usually bought from neighbours) by cutting away a small part of the pigs' ears so that the family can easily recognize which pigs belong to them. 
A crew from England making a documentary film and I were in Simatalu in 1998 when a father of a family performed the ritual for his son's new house. We were allowed to experience the entire process and make a documentary of it (Wawman 1999). We witnessed the father sacrificing four pigs for his son's new house and for his son's wife who was pregnant. The father "read" a prediction of good luck, good health and prosperity for his son and the rest of the family when he examined the hearts of the ritually blessed and ritually slaughtered pigs. This sort of augury is not limited to pigs, Mentawaians might also read their fortune by examining the intestines of ritually blessed and ritually slaughtered chickens.

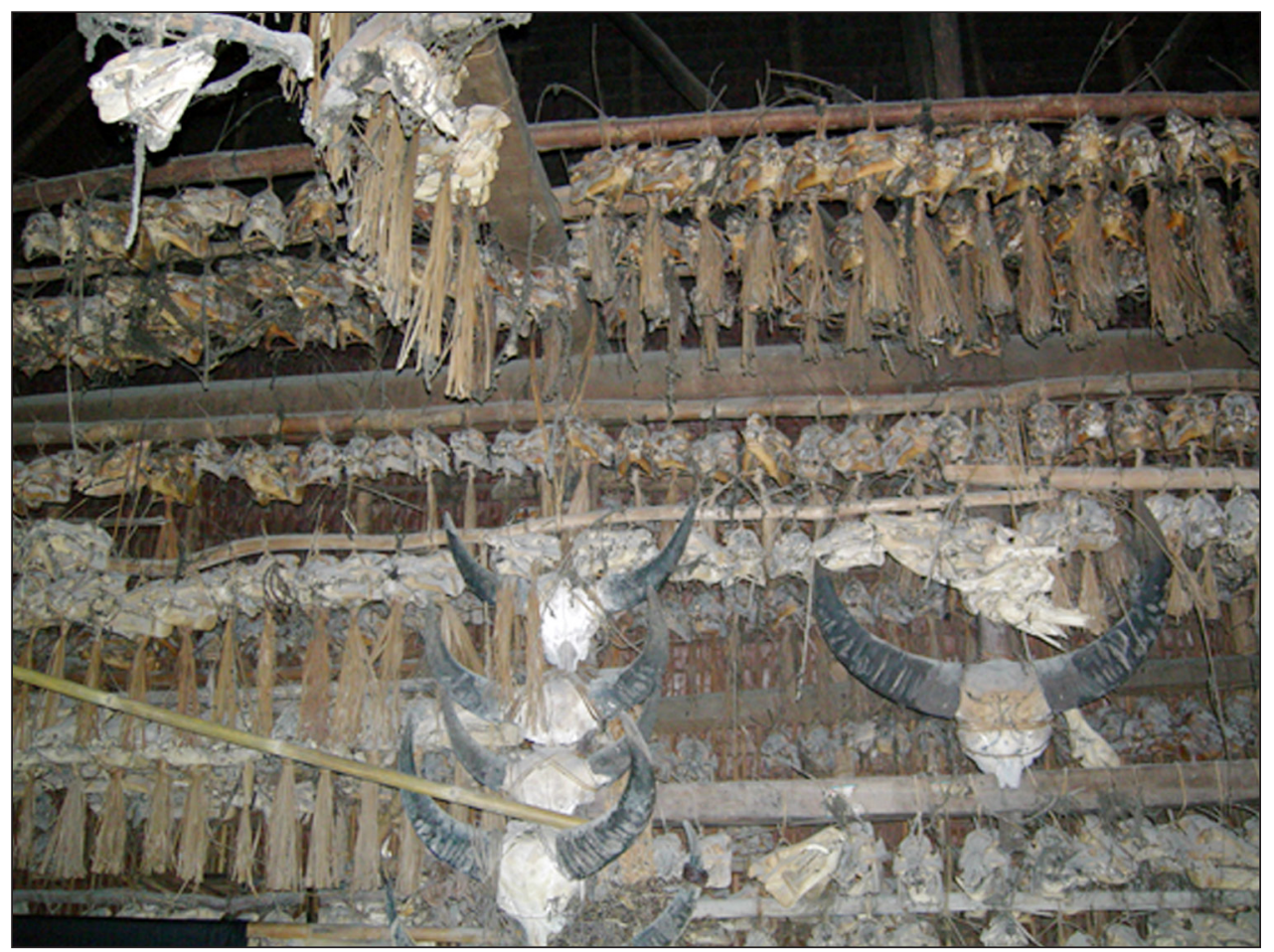

Picture 2. Pig skulls and buffalo horns are kept in the communal house (uma) of the Sakuddei kin group in the upriver village of Sagulubbe (photograph by the author, 2006).

The skulls and bones of the ritually slaughtered pigs are collected in a special part of the family house (see Picture 2). The Mentawai communal house (uma) is generally divided into four sections: the laibokat (veranda) at the front of the house; behind that, the abut kerei (where people make a fire for rituals); behind that, the puturukat (where people usually perform dancing during rituals); and at the back of the house, the bailigat or katubaga (where women and children sleep and cook daily meals, separated from men, who sleep in the other two rooms). In this room, the ritual leader (rimata) places a ritually blessed cluster of leaves called bakkat katsaila, for the protection of family members and the family inheritance as well as to bring the family blessings 
and prosperity. The laibokat and the abut kerei are the parts of the communal house relevant to the ritual slaughter of pigs.

The skulls and bones of domesticated animals are kept separate from those of wild animals. The skulls and bones of wild animals like monkeys, deer and wild pigs are placed in the abut kerei, tied to a wooden board above the fire. Whenever people cook meat ritually, these skulls and bones become warm and smoky, which propitiates the forest spirits. In the Mentawai way of thinking, people are not responsible for taking care of animals in the wilderness. This is the task of the forest spirits. After the meat of wild animals has been eaten, the skulls and bones are placed near the fire as a sign of respect. Mentawaians assume that the forest spirits will be glad and will bring the family prosperity if they see that it has been taking good care of the skulls and bones of wild animals. The skulls are positioned towards the outside of the house, communicating to the spirits of other wild animals still at large in the wilderness. If people show the forest spirits proper respect by performing the appropriate rituals, they will have better luck hunting and will catch wild animals more easily. Furthermore, the forest spirits will not be angry with the hunters.

In contrast, Mentawaians tie the skulls and bones of domesticated animals, mostly pigs, to a wooden board on the laibokat, far-away from the abut kerei. Hanging these skulls of domesticated animals outside the house and far away from the fire is meant to allow the bones to be "possessed" by the cold. These skulls and bones of domesticated animals do not need to be warmed, because Mentawai people have taken care of them throughout their lives, before they were slaughtered. The skulls and bones are positioned towards the inside of the house. By doing so, the spirits of the slaughtered pigs can remain in the vicinity of the house in which they were raised.

Besides their place in rituals and daily meals, pigs are highly valuable as payment in a variety of social transactions. Bride-prices (alat toga) and fines (tulou), which can also be substituted by plots of land, are commonly paid by surrendering a few pigs. Ibat pangurei (the wedding feast) is prepared by slaughtering pigs. The bride's family give the slaughtered pigs to the family of the bridegroom. The size of the pigs slaughtered for the wedding meal indicates how high was the bride-price the bride's family requested. Pigs are also used given to family members residing elsewhere as gifts or to friends as a symbol of friendship. Above all, having many pigs is important to Mentawaians, because it says something about people's status in their community: they are simasakkoko or 'people who have pigs'. Raising pigs is meant to satisfy the Mentawaians' daily need for meat, to form exchange relationships, as recompense for social misdeeds and for use in rituals. In a nutshell, pigs are very important to Mentawaians.

\section{A FAMILY STORY OF A CRUEL CONFLICT OVER A PIG}

The particular pig story presented in this paper tells the tale of two different kin groups which were involved in a dispute. It has been adopted from 
Chapter 6 of my unpublished PhD thesis entitled Family stories; Oral tradition, memories of the past and contemporary conflicts over land in Mentawai - Indonesia (2012). I evaluate the pig story in order to understand significant elements in it. I begin by looking at the pig story collected from the Salamao kin group residing in the village of Taileleu. Subsequently, I focus on a story from Sioban on Sipora. The order of the two stories below simply follows the order in which I collected them.

\subsection{THE PIG STORY AS TOLD BY THE SALAMAO KIN GROUP}

Terig Kerei also known as Aman Maom (the father of Maom) (see Picture 3) was a senior shaman. He passed away a few years after I had met him several times in 2004. As Aman Maom was one of few people who had an extensive knowledge of traditional Mentawai culture in Taileleu, I was very lucky to be able to gather information from him. He was seventy-eight years of age when I recorded the pig story of the Samongilailai. His current kin group called the Salamao came originally from Samongilailai where the group first lived in Simatalu located in the western valley of Siberut. The whole story of how the Samongilaila turned into the Salamao and how the group now happens to live in Taileleu is given in Story 1.

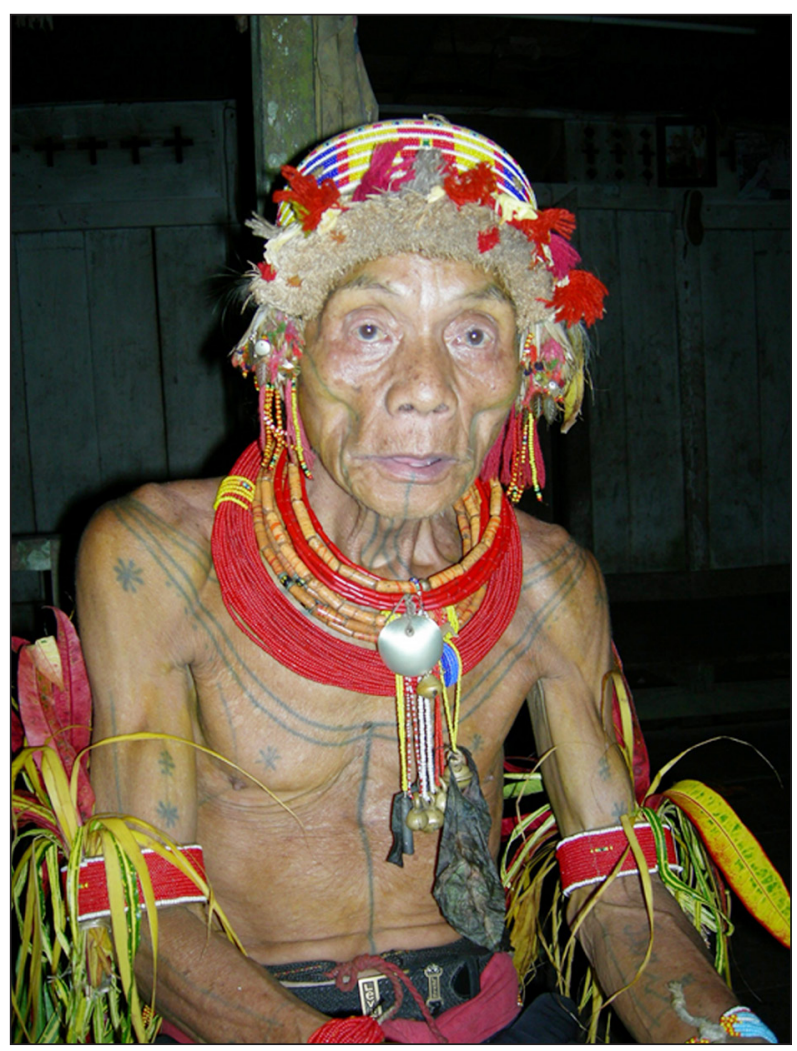

Picture 3. Aman Maom Salamao (78 years old), the senior shaman and respected storyteller of the Salamao kin group (photograph by the author, 2004). 


\section{Story 1}

We moved away from Simatalu because we became involved in a dispute with a kin group called the Sapokka. The dispute was about a pig. My ancestors told me a story which we must always remember. The story is as follows. Our ancestors lived in Simatalu, and the Sapokka [kin group] became one of our ancestors' neighbours. One of the Sapokka sons married one of our ancestors' daughters. Emeiboblo was our most prominent ancestor at the time the assault occurred. The Sapokka offered him a pig as bride-price. Therefore, initially our ancestor had great respect for the Sapokka.

One day, the Sapokka shot the pig which had been given as our ancestor's bride-price. After shooting the pig, the Sapokka families ignored the fact that their daughter-in-law was from the Samongilailai. She seemed to recognize the pig and she asked about it, but they did not tell her the truth. A few days later, her father, Emeiboblo, came to visit the Sapokka, "Perhaps, you have seen my pig, my dear relatives-in-law ( $k a d d e i)$. I have been missing it these past few days. I suppose the pig has returned to you, as it came from you. Therefore, I came to ask if you had seen it here lately." The Sapokka denied it, "No, we have not seen any pig which we had given you"' Of course, the Sapokka deliberately lied to Emeiboblo and his daughter overheard their conversation.

Afterwards, she went to visit her father's house and revealed everything she knew about the pig which the Sapokka family had eaten in recent days. Having listened to his daughter, Emeiboblo decided to extract a fine from the Sapokka. Emeiboblo sought some people as mediators (sipasaili or sipasuili) in order to negotiate the settlement of the quarrel which had arisen between him and the Sapokka. The negotiators arrived at the Sapokka's house, "We come to represent Emeiboblo whose pig has been shot and eaten by you. Emeiboblo has already found out that his pig was shot because his daughter has told him about it. Therefore, we now come to ask you to pay a fine for the pig shot (tulou saina). You have to pay Emeiboblo a pig to make matters good with him again." After hearing the accusation, the Sapokka said, "So, that is the reason why you come here. Emeiboblo found out about his pig from his daughter. Because the daughter reported us to her father, we are not going to pay the fine. We admit that we shot the pig for a special purpose, but we are not going to pay the fine." The mediators returned to Emeiboblo reporting what the Sapokka had said. However, Emeiboblo tried to calm the matter down. He postponed discussing the case, he postponed, postponed, postponed seeking to find another way to urge the Sapokka to replace the shot pig. Emeiboblo needed some time to think about it, but he did not take long enough.

After waiting a few days, Emeiboblo sharpened his machete and spear. He did not take his bow (rourou) and poisoned arrows (silogui) when he visited the house of the Sapokka family. He tried to remain inconspicuous as far as the Sapokka were concerned. At the house, the Sapokka family members were cooking bananas. Emeiboblo addressed a question to them as he was sitting next to them, "Why do you not fulfil the request of the negotiators whom I sent to talk to you, namely: that you have to pay me a pig as replacement for the one you shot?" The Sapokka deliberately ignored Emeiboblo's request and answered him, "We do not want to pay it because we just do not want to do so. If you want to have it you have to do that with the shiny, sharpened machete and spear." As he stood up, Emeiboblo said, "I shall do as you wish." And the next moment he threw his spear to hit the person who had answered him, who was cooking 
banana, and then swung his machete at another person sitting next to him. The rest of them ran away out of the house. Then Emeiboblo returned home.

However, this incident did not frighten the Sapokka at all. They prepared their hunting gear and pursued Emeiboblo to take their revenge for the deaths of their two brothers; the brothers who had been killed by Emeiboblo. Before the Sapokka arrived, however, Emeiboblo and his family had left for a place located on a hill called Sigarena. They built a shelter and they opened a garden (mone) as well.

While in exile, Emeiboblo's younger brother wanted to return to Simatalu. He asked Emeiboblo for permission for himself and his family to return to Simatalu, "As a matter of fact, it was not me who was involved in the violence against the Sapokka. I have decided that they are not going to use violence against us. If all of us leave our place, houses and pigs [permanently], we are losing a great deal. They are going to take these things away from us. If you do not mind, my family and I will return to our place." Emeiboblo allowed his younger brother and his family to go back to their home. "You may return and take care of our chickens, pigs, house, land and gardens. We still have a few pigs there. They are very important to me. One day we shall return to visit you, I promise!" So, some members of the Samongilailai did return to Simatalu. Emeiboblo and his family remained in the place called Sigarena. He fed his chickens with wild palm trees (batariribug). Emeiboblo's younger brother's family who returned to Simatalu were Lajomanai's ancestor (punuteteu Lajomanai), Moggui's ancestor (punuteteu Moggui) and Sisilogpa's ancestor (punuteteu Sisilogpa). [These are names of three people currently living in the village.]

When the Sapokka heard about the return of the Samongilailai, they prepared themselves to do violence. "So, have the Samongilailai returned? Let us make a deal with them!" The Sapokka decided to make an agreement with the Samongilailai. Samongilailai was the name of the kin group of Emeiboblo and his brothers. The Sapokka arrived, "We have come to make a deal with you about the death of our two brothers." The Samongilailai said, "We have nothing to do with the hostility. Our brother, Emeiboblo, was the culprit. He is now in Teitei Sigarena. If you want revenge, you can visit him there. But we suggest you do not go there because perhaps they have already left for a new place, and there is also a possibility that all of you will be shot by him." At the place called Teitei Sigarena, Emeiboblo lived with his relatives. One of the relatives was a person called Pajorot. He was the ancestor of the descendants who migrated to Sipora. Another relative was the ancestor of those families who moved to the place traditionally called Tateiku [currently the location of the government villages Berisigep and Sigappona], and also the ancestor of those families who later moved to the place called Cempungan.

As promised, Emeiboblo visited his brothers and the rest of the family in Simatalu. The family still had pigs and Emeiboblo wanted to take his share. When he visited them, the brothers were processing sago from the palm trunk to make flour to cook for their daily food. Upon his return, Emeiboblo wanted to know whether the Sapokka had still looked for violence after the return of his brothers and their families. Emeiboblo was not ready for violence; he had always been afraid of the Sapokka. He therefore hid himself in the house. However, he still felt insecure. He went to climb a tree called a toilat. He took with him a jackfruit (peigu) in order to fill his stomach while he was in the top of the tree. Some of the seeds of the jackfruit fell down near the root of the toilat. As evening 
fell, when his brothers returned to process sago, he returned home, too. "I have just returned from the toilat tree. I ate jackfruit there. If one day the jackfruit has begun to grow there, you should remember that its fruit belongs to me and this means they belong to you, too."

Thereafter, they sacrificed pigs and Emeiboblo took his share and early in the morning returned to his family in Sigarena. Emeiboblo departed with the help of his brothers, "You will accompany me and soon after I have arrived, you may return home." They went upriver, upriver and upriver. While they were paddling their canoe, Emeiboblo introduced his brothers to their land and its borders, including its rivers. As they were approaching the big river mouth, they turned to enter the small river called the Polime. They kept paddling, "This is the river called the Polime and the land in this area belongs to us." When they arrived at an area in which they found many rattans, Emeiboblo stated, "This is the border of our land. I have shown you where its border commences. It begins from there as far as this place where we are now. All of this is our land."

He arrived at Sigarena but he did not continue to migrate in the direction of Cempungan (in the northern part of Siberut), instead he chose to migrate southwards to Silaoinan. He moved there and afterwards claimed a plot of land. He did not find any marks of other people indicating other people's claim to the land, so he claimed the land himself. But when he arrived at the river mouth at the place called Mongan Masat, where to the right is the river called the Bat Sapsap, he carried on to the upriver place called Tirit Sapsap where he stopped. He then returned whence he had come initially. All the rivers and plots of land lying within the borders, bearing such names as Mongan Sirau, Mongan Koddobat, Bat Mapiligi, and further downriver Bat Silaoinan, were claimed by him as the property of Emeiboblo and his relatives.

In order to secure the borders of the land, Emeiboblo and his brothers retraced the course of the river called the Bat Masat and reached the upper part of the river. They stumbled up hills. They passed through forests on the top of hills, top of hills, top of hills, top of hills. When they arrived in the upriver place called Tirit Magoga, where there were river mouths called the Mongan Lamao and the Mongan Mongilailai, they came across a forest path along which many people from Simatalu walked, leading them to the upriver place called Tirit Samukop, and then they arrived at Sigarena, where Emeiboblo's lands were situated.

Soon after he returned, he told members of his families, "We have extensive land and I shall tell you its borders. Those lands located outside of the borders do not belong to us, because other people had claimed them before us. So, in order not to provoke any conflicts, you will not claim any of them. But land inside of the borders is ours; that land belongs to us, the Samongilailai."

After they had settled in Sigarena for some time, they began to expand. The ancestor called Sipajorot was a relative of Emeiboblo. He moved away from Siberut. Sipajorot and his family began to leave Sigarena and arrived at the river mouth called Mongan Sarabua; on the right side they passed by a place called Sirau. Some of them moved to Cempungan, but they did not stay there long. When a harsh battle among Mentawaians took place in Cempungan, they left Cempungan and went to Saibi Samukop. After that they occupied a place called Malamit. Then they moved to Maileppet. The Sibeutenga and the Siliggai are Sipajorot's current descendants, who are now dwelling in Maileppet. Other families immigrated to Sipora.

The rest of Emeiboblo's relatives moved from Sigarena to the riverbank of 
the place called Magoga. Later they moved again to the riverbank of the place called Lamao. Thereafter they were called the Salamao. We are the Salamao, who descended from Emeiboblo. Because we lived in the place called Lamao, we acquired a new kin-name, the Salamao. We stayed there, we stayed and stayed and stayed, and later moved on to inhabit the river mouth of the place called Bebetratci. Then we moved to the river mouth at the place called Mongan Palakkokoai, precisely at the place called Sirigdig. From Sirigdig we continued to migrate to here in Taileleu. Our ancestors moved from Sirigdig to Taileleu, because people were hunting them. Those people were called the Sabirut. [The storyteller does not explain who the Sabirut were. He probably meant people living in the south-eastern part of Siberut.]

A niece of Emeiboblo was terrified and ran away to hide herself from the sight of the Sabirut, so that her body wrap dropped off and she was consequently naked. The Sabirut found out that the woman was a family member of the Samongilailai. The Samongilailai requested the Sabirut pay a fine for the embarrassing incident. The Sabirut paid that fine by sacrificing their pigs. However, the payment did not satisfy the Sabirut, as they knew that the woman was a member of Emeiboblo's family and hence belonged to the cruel Samongilailai. Therefore they assumed that the Samongilailai would eventually kill Sabirut.

In order to convince the Sabirut, the Samongilailai slaughtered a sigelag pig [sigelag is a particular size of pig, one weighing 50 to 60 kilograms], as a token of the Samongilailai's goodwill. The Sabirut put the pork into bamboo tubes; this way of preparing pork is called siliglig [this term is later used to name a plot of land]. In their turn [as a favour to the Samongilailai], the Sabirut were willing to accompany the Samongilialai on their journey to their land at the river mouth at the place called Mongan Masat. The Sabirut said, "As you said that you have plots of land located at the place called Bat Masat which borders on our land, too, we would like to accompany you there so that we can show you the borders of our land."

So, from the river mouth at the place called Sabirut, they went upriver to a place called Silaoinan. On the way, they passed a place called Kairogdag. When they arrived at the place called Mongan Masat, the Sabirut said to the Samongilailai, "You can take the land called Masapsap on the left side of the river Bat Masat. The land belongs to us, but Masapsap is now yours as payment for the humiliation of your sister; this land will be called porak tulou pakaila (land for expunging humiliation) but it is also called porak siliglig because of the pig you slaughtered for us, showing your goodwill." The Samongilailai stayed there and their numbers grew.

Some of the Samongilailai moved again to another place located at the mouth of the Rogdag River, where they planted mango trees (abbangan), sago palms and bamboo groves. They also built an uma. In that place some of them decided to split up into several groups. The ancestors of the kin group called the Saeppunu decided to live separately from the Samongilailai, hence they emerged as a new kin group. The Saeppunu moved to the mouth of the Siberut River. One of their current descendants is known by the name of Satalojo and resides in Puro. He is the present leading figure in the kin group. Some of our other relatives moved away to a place called Sirau and became the Salakkokoai kin group. Their current descendants are Aman Sila'luppa and his family, Taigojongenda and his children, and Sibulauseddet and his family.

Some of the other Samongilialai split up to become the kin group called 
the Sakoddobat who moved to a place located in the mouth of the river called Koddobat. They built an uma at the river mouth and later moved again to the place called Mongan Simapiligi, where they planted sago palms. The course of our own expansion in the kin group called the Salamao began in the place called Mongan Koddobat. One of the offspring of Emeiboblo was Sikora. Sikora had seven sons and a daughter. The daughter married a son of the Saleilei kin group. Therefore we have a family relationship with that group through marriage. Sikora's sons were Simateingorut, Simateimut, Siturugougou and others whose names I can no longer remember very well.

Then, we as Salamao moved to the river mouth at the place called Mongan Kerengan. Four sons of Sikora's children migrated to the place called Bat Sirileleu (now called Taileleu). Sioremanai was the ancestor of the Samongilailai; Sisilakkerei was the ancestor of the Salakkokoai; Sigorottai was the ancestor of both the Salamao and the Siturugougou. The four ancestors and their families migrated to the riverbanks at the place called Sirileleu (now called Taileleu). At that time we moved away, because other people in northern Siberut had begun to indulge in violence. Satubeken and Saseppungan began it. Consequently, our ancestors moved away and arrived at the upriver place Sirileleu. When they arrived in Sirileleu, our ancestors met the kin group called the Sakaloat; the Sakaloat were the landowners (sibakatlaggai). The Sakaloat agreed to our ancestors settling in their lands. Our ancestors did not have any right to possess land there because the earlier inhabitants, the Sakaloat, had been the first to occupy the land in Sirileleu. Our ancestors were given the opportunity to build their houses and have a plot of land to use to make their own gardens, but they did not have rights to the land on which their gardens were located.

After they had settled there for some time, they had plenty of chickens and pigs. So they gave some pigs to the landowners as payment for the plots of land they had used to build their houses, raise chickens and pigs and open gardens. Chickens and pigs were valuable currency at that time. Later, our ancestors became involved in disputes with the landowners, and they decided to part company with the landowners. Our ancestors of the Salamao group, who are also the ancestors of the Samongilailai and the Salakkokoai, moved away in order to avoid conflict with the landowners. Consequently we went to inhabit a place located downriver of Sirileleu. The Salakkokoai inhabited a place located at the river mouth called Sisugsug, and we Salamao settled in the place on the opposite side of the river of Sirileleu, where the river mouth of the place called Sisugsug is located.

One day the Salamao and the Salakkokoai became embroiled in a dispute about insulting each other's wives. The dispute had created bad relations between the two groups. In order to calm down the dispute, the Salamao paid the Salakkokoai sago palms located in five different areas and received from the Salakkokoai a big pig with brown skin (babui siboje). Afterwards, we settled down and continued to plant sago palms and to raise pigs and chickens. After we had finished planting our gardens and raising pigs and chickens, one of us called Simateipara went to set his trap (mutapi) to catch animals in the forest. He caught plenty of game and at that moment we came together with the Sakaloat, the landowners in Sirileleu, for a second time. Unfortunately, our good relations with the landowners were short-lived. We had to split up again and separate from them. We no longer wanted to settle with them. In order to leave the landowners, we had to pay them four garden plots (epat ngamata mone), a huge pig (babui), four 
baskets of chickens (epat log manu'), and an iron wok for cooking (okali). We had to pay for all the costs of the things we had used and received from the Sakaloat. We paid for our own independence.

Before we were definitely separated from the Sakaloat, they reminded us, "Because all of you who are descended from the kin group called the Samongilailai, including the Salamao and the Salakkokoai, no longer want to join us, we would like to remind you that if you go upriver to the place called Bat Mabilabilag, that is the border of the place at which you can plant and harvest things. For your information, if you [go farther upriver and] arrive at the mouth of the Kaloat River, you must always remember that you are entering the borders of the lands belonging to us. You should not hesitate to enter them. You can hunt animals in the forest on our lands but you must not take any rattan or other valuable natural resource. You can also make your own garden if you like." But we did not want to get into trouble, so we keep our distance from them. We, the Salamao, remained downriver. Some members of the Salamao group settled at a place called Bat Limu and they acquired a new name, the Salimu. The Salimu are now independent as a new kin group. They have their own uma. However, we are still related to them ancestrally.

We are currently occupying the place we bought from the landowners. But our former lands have been left in the hands of our relatives at a place located along the banks of the Koddobat River in Silaoinan and at a place around the hill of Sigarena. Those places are our ancestral heritage. We shall not allow anyone else to take them away from us. Other people cannot freely exploit the natural resources which are available in those places. This story I am telling you was told to me by Siruate'te', my ancestor. He was descended from Emeiboblo. He told the story to my father. Now I am an old man and I am going to tell the story to my sons and grandsons. (Narrated by Terig Kerei (Aman Maom) Salamao, 78 years, Taileleu - Siberut, 2004). (See also in Tulius 2012a: 140-146).

It seems to me that the storyteller remembers the past well and he recounts his pig story in a chronological sequence, beginning from homeland down to the current settlements in which some of his relatives reside. The storyteller mentions three main events in his pig story. The first is about the life of the Samogilailai kin group in Simatalu. The second is the migration of the Samongilailai who left their home in Simatalu to explore some places in the valley of Silaoinan. In the course of this he also narrate the change of the Samogilailai kin name to Salamao. The third is the life of the Salamao in Taileleu. The storyteller demonstrates his familiarity with the ancestral narrative of the Samongilailai kin group through a detailed recollection of the pig-killing incident, place-names and locations of plots of land, numbers of families founded in the course of migratory movements and the names of his other ancestors who had led the group in its move away from Simatalu. He also recollects some ancestors of the Samongilailai who had led their families away to create new kin groups. Pertinently, while explaining the splitting up of the family the storyteller does not talk explicitly about his particular ancestors who created new kin groups. Instead, he replaces these names with the names of current descendants of those ancestors. Consequently, rather than learning the ancestors' names, we are given the current names of the offspring 
of those ancestors. Now, in order to find the connection between the Salamao and the Samogilailai, I present the pig story gathered from the Samongilailai on the island of Sipora. The pig story of Samongilailai is presented in the next sub-section.

\subsection{THE PIG STORY AS TOLD BY THE SAMONGILAILAI KIN GROUP IN SIOBAN}

Sioban is one of several older villages on the island of Sipora, where I met another group of the Samongilailai in 2004. This kin group claims to be the owner of the place and land in Sioban. According to the Sioban villagers, the Samongilailai was the first kin group to settle permanently in Sioban. Among the Samongilailai, I met several elders; however, only a small number of them knew their family pig stories. One of those people was Gustap Samongilailai (see Picture 4).

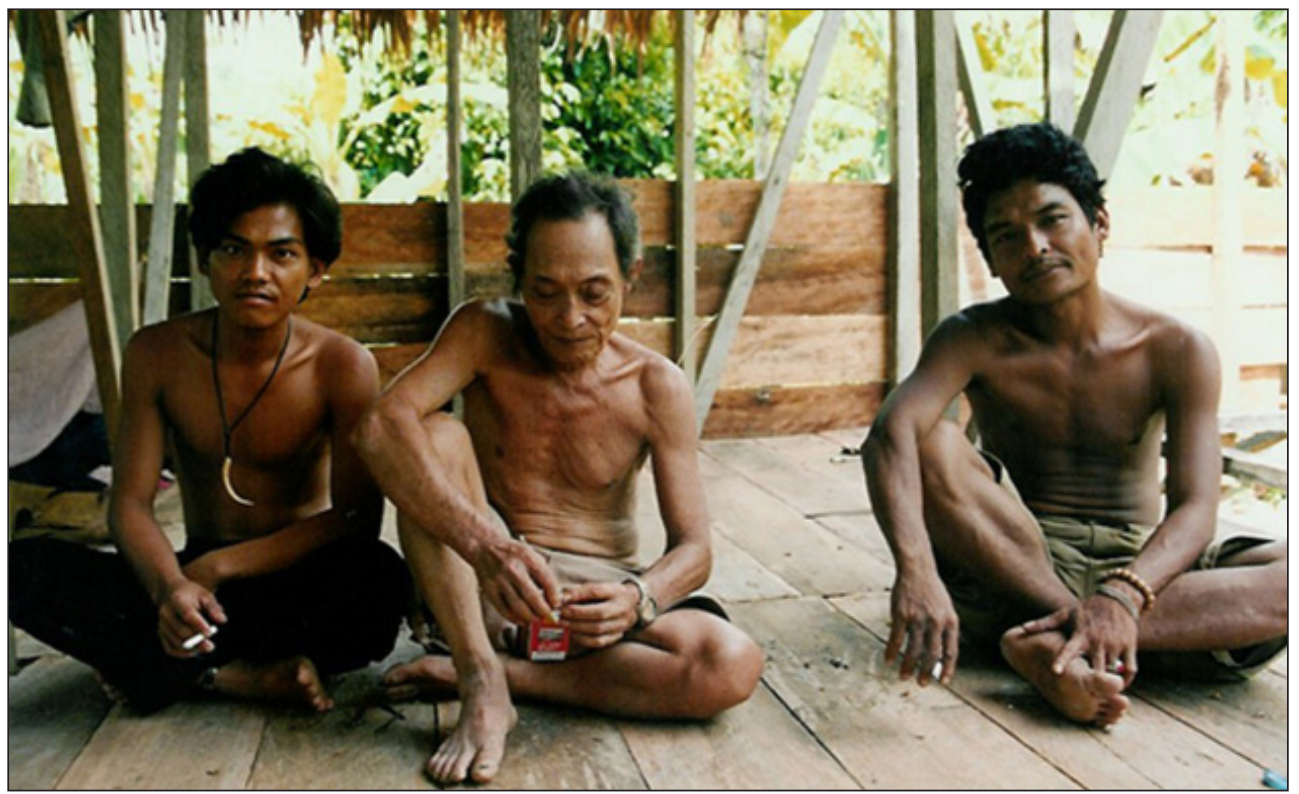

Picture 4. Gustap Samongilailai (63 years old) (in centre) and his two sons in Sioban on Sipora (photograph by the author, 2004).

I disturbed him as he and his sons were building their house in their land. He told me that he needed to build the house on his land as more and more people were coming to Sioban to settle. Because of the growing population pressure, people were simply grabbing someone else's land in order to build a house. If a landowner happens to be tardy in stopping newcomers constructing a house, it is hard to eject them. As the years pass, landowners will have increasing trouble reclaiming their land. The newcomers are in no mood to give the land back. Therefore, his best strategy is to build a house on his land rather than allowing others to use his land. As they are on the spot, he and his sons can also keep a close eye on the land. He narrated the pig story while his two sons 
were seated around us listening. The story is as follows.

\section{Story 2}

In the beginning, while we were still living in Paipajet, our kin group was called the Saurei. The name of our ancestor was Siranjau. He had two sons. I do not remember the name of the older son, but the younger son was Simatatlaggai. He was our ancestor. Simatatlaggai moved away to dwell on the bank of the Matalu River in Lubaga. His older brother remained in Paipajet.

When our ancestor arrived in Lubaga he found a plot of land whose borders adjoined the borders of land belonging to the kin group called the Sakerebau. The land was located on the riverbank at the place called Baibai. It included the upriver portion of the place called Lubaga, at which point the land adjoined land belonging to the kin group called the Sirirui. The border here was called Kalaimurau. The border extended as far as a place called Sirilogau. These were the borders of our land claimed by Simatatlaggai in Lubaga. In Lubaga, a small river called the Bat Simaottot was used as border of our land as well. That border adjoined land belonging to the descent group called the Saelet. When our ancestor Simatatlaggai was in Lubaga settling at the place called Mongan Lubaga, more precisely called Siatsemi, he had sons and daughters. They were named: Emeiboblo, Pabelemanai, Maliggai and I do not remember the name of one of the daughters. Maliggai married a son of the descent group called the Sakoikoi, and the Sakoikoi were the closest neighbours of our ancestors. They became what are known as the teitei uma [neighbour, literally 'behind the house'] of our ancestors. The Sakoikoi occupied a place in an area called Lebbekeu. Some of the Sakoikoi split off in order to become the kin group called the Siritoitet. Another of our ancestor's daughters married a son of the kin group called the Sapokka. When they lived in Simatalu, our ancestors raised pigs. One of their pigs went to root in the ground in order to feed itself in the valley near the place the Sapokka occupied. The Sapokka shot the pig. Afterwards, they [members of the Sapokka group] brought it home and they ate the pork. Emeiboblo's sister saw the pig. She recognized that the pig belonged to her father and brothers. As the Sapokka, including Simatatlaggai's daughter, were eating the pork the daughter saved a small piece of the pig's cooked skin. She dried the skin in the sunshine. One day, the Sapokka's daughter-in-law asked her husband's permission to visit her father, Simatatlaggai. Her husband allowed her to go. In the meantime, Emeiboblo and his brother and father were searching for their pig.

She went to visit her family and she took with her the skin of the pig. She rolled it up in her hair. When she arrived at her father's place, she asked her sister who had married a member of the Sakoikoi group to comb her hair. In that way, her sister found the skin of the pig, "What is this? It looks like the skin of our missing pig." They showed the skin to their brother, Emeiboblo. Emeiboblo asked when the Sapokka had killed the pig. From the information his sister gave, he realized when he had begun to miss the pig. Emeiboblo took a dim view of this event. He decided to extract a fine from the Sapokka.

Emeiboblo informed the Sapokka, "I have come to your house today to seek payment for the pig you shot, which belonged to me." The Sapokka did not want to pay and said, "If you want to be paid, you can take your payment from our sharpened metal-tipped arrows (tunung)." Emeiboblo did not want to become involved in a serious dispute with the Sapokka because they had become relatives by marriage. But he did want to be paid the same size of pig as the one the Sapokka 
had shot. The Sapokka refused to pay. So Emeiboblo returned to his house and reported to his family what the Sapokka had said. Emeiboblo and Pabelemanai prepared to attack the Sapokka. They sharpened their machetes and spears.

At cock-crow next morning, they went to the house of the Sapokka. It was early in the morning. When they arrived at the place, Emeiboblo killed one of the Sapokka. Other Sapokka went after him and his brother. Emeiboblo hid himself by climbing a tree called a toilat. He took his spears and bow and arrows up the tree with him. He hid there while the Sapokka looked for him and then returned home. Some Sapokka came near the tree but they did not see Emeiboblo. The Sapokka wanted to go to Emeiboblo's house but they hesitated to do so, because they anticipated being shot by the rest of Emeiboblo's relatives. The Sapokka decided to return to their house. Next day, they again went to hunt Emeiboblo. They did this several times. Emeiboblo decided to leave his brother and the rest of the family, because the Sapokka were hunting him almost every day. He and his family left to find a new place.

Before Emeiboblo left, he handed over rights to their land, gardens, vegetation, animals, and other possessions to his brother, Pabelemanai. Emeiboblo said to Pabelemanai, "My family and I are going to leave you to settle elsewhere; you are going to remain here for the rest of your life. You have to take care of our gardens and our other possessions. You must know the borders of our land. Leleu Simagerettobat belongs to us. This hill is a large one. This hill is bordered by land belonging to the Sakerebau and the Sakoikoi and lies opposite the villages of Simalegi and Sakatiri. The adjoining land belonging to the groups called the Siritoitet and the Saoppu, and finally it lies adjacent to the land belonging to the Sakerebau." Emeiboblo reminded his brother about the other lands and rivers which belonged to them. The lands and rivers were situated at the place called Bat Saibi Simatalu. The borders of their land, including rivers, began at the river mouth of the Bat Saibi Simatalu extending upriver to a place called Kulumen. Another piece of land, Emeiboblo told his brother, was named Teitei Sirigdig. The entire hill belonged to the Samongilailai. After all was in order, our ancestor commenced his migration. He stopped at a place called Teitei Sigarena. At Teitei Sigarena, Emeiboblo built a shed and planted a mango tree (abbangan). Teitei Sigarena was divided into two parts. One side of the hill belonged to the group called the Siriratei and the other side belonged to us. After remaining there for some time, Emeiboblo moved to a place called Sirilabat because the son of his sister lived there. Sirilabat was located in the upriver valley of Saibi Samukop. While Emeiboblo was staying in Sirilabat, he asked his nephew if there was land which other people had not yet discovered (siau). It took Emeiboblo and his family eight days to accomplish a trip in order to ensure himself that other people had not claimed the land. They arrived at a place called Bat Simapeleku'. Having stayed with his nephew, Emeiboblo decided to leave again. He had made a canoe beforehand. The canoe was made out of a durian tree. This durian was called togtug sinikki baga. The durian belonged to his nephew. After the canoe was completely finished, Emeiboblo and his family moved downriver and arrived at a place called Bat Koddobat. They claimed Bat Koddobat as theirs.

At this point, the storyteller paused telling me the story. He called my attention to a finch's song. The bird was singing clearly in the daytime. This bird is called kuilak in Mentawai. Mentawaians believe this particular bird is a special 
sign if it sings on particular occasions. The bird sounded as if it was close to the house, but we could not see it. The storyteller told me that what he was telling me was the truth, and the song of the kuilak confirmed that it was the truth. After he had told me about it, another animal made a sound. It was a small house lizard, called supsup in Mentawai. The sound made by the animal was interpreted in the same way as the song of the kuilak. He then continued telling me his story. I noted it in my notebook so that I can include the moment here while presenting this story because the moment was important to the storyteller himself.

They then moved downriver again until they arrived at a place called Bat Siriano. But Sibubu and Sitoggro had occupied this place first. Emeiboblo and his family met Sibubu and Sitoggro, who invited them to stay with them there. When Emeiboblo and his family stayed in the house of Sibubu and Sitoggro, the two hosts beat their wooden drums (tuddukat) to inform their neighbours and relatives to come. They transmitted messages telling of the arrival in their place of Emeiboblo and his family. The messages transmitted by Sibubu were: "Neighbours and relatives, you have to come and bring along with you sharpened tools, spears, arrows and bow and machetes in order to eliminate people from Simatalu."

Soon after that, some people arrived at the house of Sibubu and Sitoggro. Those people immediately wanted to kill the people from Simatalu, namely: Emeiboblo and his family. But Sibubu and Sitoggro stopped them. They said, "We are not going to kill anybody today. We have invited you here in order to introduce you to our new relatives $\left(r a^{\prime} r a^{\prime}\right)$. So, if you see them opening gardens or gathering food, you know that they are our family (saraina). Consequently, you shall not kill them."

Thereafter, Sibubu introduced Emeiboblo and his family to those people. They lived there together in peace. Everybody came to bring something for Emeiboblo and his family. They brought coconut seeds, young sago palms and other trees for Emeiboblo to plant. A feast was organized. Emeiboblo dwelled in the place and had some children. They were Sisausau, Sikora and the ancestor of the Sabeleake whose name I do not remember, and a female called Situkai. The Sibubu and the Sitoggro accompanied Emeiboblo and his family upriver, where Emeiboblo and his family could plant all the seeds he had received from people who had initially come with the intention of killing him.

On the way upriver, Sibubu requested Emeiboblo to bend his bow and fix an arrow in it. Emeiboblo was to stay on one side of the riverbank, while Sibubu with a spear in his hand stood on the other side. They stood opposed each other. Emeiboblo did not understand why Sibubu had asked him to stand opposing him. Emeiboblo said, "I have seen ulaunia manua [literally, the light of the sky; meaning I have survived] because of you, now you want me to bend my bow and fix an arrow in it. Are we going to kill each other?" Sibubu answered him, "Emeiboblo, my best friend (siripo'), you must listen to me very carefully and remember what I say to you. What I want to say to you must also be remembered by our offspring (sapunuteteuta). I have given you seeds of sago palms, and now I am going to give you a plot of land on which you can plant them. Commencing from here, at the river mouth of a place called Bat Simasapsap, and extending upriver until you reach a place called Bat Koddobat, you must enter that place and continue 
to the upper reaches of that river until you encounter a river which is divided into two water courses. You have to follow one of the rivers called the Bat Limu, until the end of this river where you can no longer find any water. These are all borders of our land. What I have just told you are borders of the land on which you can make your own gardens. The land enclosed within those borders now belongs to you and your descendants." After Sibubu explained the borders, he stated clearly to Emeiboblo, "But my best friend (siripo') Emeiboblo, you must be aware of the fact that if you come downriver intending to expand the borders of the land I have given you, claiming it as your new land, this, my spear, is going to strike your body dead." Soon after he finished speaking, Sibubu forcefully struck his spear into the ground, thereby breaking its wooden shaft. This moment symbolized their agreement. "Now I see your point, my friend. You have given me your own land, you have even sketched the borders of which land is going to be mine and which land was initially yours. But my friend, you have declared to me that I cannot take over your own land except the land you have given me. If I were to take over or expand the borders of the land given to me, I am going to die by means of your spear just as you struck the spear into the ground. Now I declare to you, if you take over the land which you just gave to me, or if you narrow the borders of the land given to me, I am going to shoot you by means of my bow and its poisoned arrow." Soon after he said that, Emeiboblo released his arrow to hit a sago palm. Sibubu wanted to stop Emeiboblo shooting his arrow by replying to him metaphorically, "Hey, my friend, it is not necessary to release the arrow, it might hurt somebody." Afterwards, Sibubu closed his speech by saying, "You must remember that this land I have just given you is the land called porak pukisi (land in payment of the threat), because I asked other people to come with sharpened tools to kill you, although they did not do so." Sibubu continued, "The the bulk of the porak pukisi is located in Bat Koddobat, including the upper part of the river Bat Koddobat. But the land at the source of the river belongs to the kin group called the Sakaelagat. My own land adjoins their land, too. The Sakaelagat are the group of people who dwell in a place called Saibi." After the oral agreement was made, Emeiboblo began to plant durian trees, coconut and sago palms and bananas. He built his house where he could rear pigs and chickens and raise his children. After living in this place for some time, Emeiboblo returned to Sirilabat, where he again met his nephew, and he told him about his new land. Emeiboblo said to his nephew, "Plots of land beginning from Sirilabat as far as Simapeileiggut, including the Bat Simasapsap, and the downriver part of the Bat Koddobat belong to me. The upper part of the river including the hilly area of Bat Limu belongs to the Sikailagat." He told his nephew so that after he [Emeiboblo] had died, someone would already know which land had belonged to Emeiboblo. After he stayed, stayed and stayed at his nephew's place, Emeiboblo and his family returned to their land in Silaoinan.

One day they went fishing. Some members of his family, mostly women, remained at home. The Sakaelagat visited the place at which Emeiboblo's family were staying. They wanted to visit the family in order to have a drink or eat something. Because of the headhunting practices at that time, many people were afraid of attacks by other people. Everyone always had to be aware of everybody else before visiting each other. Therefore, when the Sakaelagat arrived at the place, all the women in the house ran away. As they were running away, those women's clothes fell off because their garments had been caught on a thorny rattan (labi). Hence they ran away without any clothes. They were naked. The 
Sakaelagat shouted, "You should not be afraid of us, because we are not going to kill you. We have come to ask for something to drink or eat."

When our ancestors returned from fishing, they found their house empty and silent. Emeiboblo searched for his family but no one was there. He thought perhaps other people had killed his family. But he did not find any bodies or any evidence indicating bloodshed. He called their names and from the bush near their house women answered him that they were hiding from other people who had just come to the place and they were naked.

Two days after this incident, Emeiboblo and his family went to visit the Sakaelagat. The Sakaelagat welcomed Emeiboblo and his family. The Sakaelagat prepared food and drink for all of them. The Sakaelagat already knew the purpose of the visit of Emeiboblo and his family and they said, "We know now why you have come to visit us. It is because of your women and daughters. When we arrived at your place, they ran away and were stripped naked because their clothes dropped while they were running away from us." Emeiboblo asked about the consequences of what the Sakaelagat had done to his family. The next day, the Sakaelagat joined Emeiboblo and his family to return to the place on which Emeiboblo stayed. The Sakaelagat gave Emeiboblo and his family a plot of land. The land was located in between the places called Bat Koddobat and Simapaddegat. This land was called porak katukaila (land paid for humiliation). Since then, that piece of land has belonged to Emeiboblo and his family entirely, and they remained in the area called Bat Koddobat, adjoining the rest of the lands belonging to the Sibubu and the Sakaelagat. Emeiboblo passed away in Bat Koddobat.

Emeiboblo's three sons were Sikora, the ancestor of the Sabeleaken, who later migrated to inhabit a place in Bat Rereiket, and Sisausau. Sikora continued to live in the valley of Silaoinan. Sisausau who migrated to Sipora was our ancestor. Sisausau was also called by the name Sipanajojo. His journey to Sirilabat began from Silaoinan. From Sirilabat, he went down to the coastal areas where he claimed plots of land located in places called Beat Torongai, Toinongonai and Tiniti (a place near the current settlement called Maileppet). When Sisausau inhabited a place called Torongai, he found a plot of land (mone) located on the riverbank of a place called Bagat Peigu as far as Sakkelo. Sisausau found signs indicating other people's occupation, beginning from Sakkelo stretching to the upper reaches of the river Sabirut. Therefore he did not claim the area. Sisausau then moved to Rereiket, where he found a plot of land in Rogdok. There he built a house and planted a durian tree (kinoso) and a coconut palm. In Rogdok, Sisausau found land in two places called Simalabi and Simapelekag. While he was living in Rogdok, Sisausau had a son called Sipajorot. Sisausau passed away in Rogdok. Our ancestor Sipajorot carried on the migration to Sipora. The son of Pajorot was Sijaja. Sons of Sijaja were two: Sisala and Sibukkutlaba.

Sisala was my ancestor. Sisala had two sons called Sisiaulaggai and Simemeuma. Simemeuma was the ancestor of our relatives who live in a place called Sao of Sipora. Sisiaulaggai was my ancestor. The sons of Sisiaulaggai were Palimaiogo, Tasibuat and Takilibet. Palimaiogo's sons were my grandfathers, called Sikatsaipeu, Sibelasot and Silulumonga. My father, named Josep, was one of Sikatsaipeu's sons. Josep had brothers named Mateus, Levi, and Benjamin. My name is Gustap and I am the son of Josep. My sons are those who are sitting next to me, listening to my story as I am telling it to you. Two of my other sons have married and already have sons. We have passed through fourteen generations 
since we migrated from our original home on the island of Siberut.

Our ancestor Sipajorot and his family arrived at the island of Sipora, on which they initially inhabited a place called Goiso' oina. When they dwelled at that place, the river there was too shallow. It was not deep enough to paddle a canoe, so they left the place. Then they moved to a place called Bagat Ureinu [currently called Saureinu], where they settled temporarily. They planted a bamboo (abre). However, the place was full of crocodiles. They were afraid of crocodiles, so they decided to leave the place and went to a place called Simatoraimonga. When they arrived at this place, many strange things happened. This place was haunted. Therefore they returned to Siberut and settled in Rogdok. Their grandfather, called Siubat ('old man'), stayed here alone. The grandfather conducted a ritual to exorcise the ghosts. Sometimes, the Samongilailai in Rogdok in Siberut went to visit their grandfather in a place called Simatoraimonga on Sipora, but they did not want to settle there. Every time they went to visit him they said, "We are going to visit our grandfather, called Siubat."

Since then this place has been called Siubat. The grandfather named Siubat returned to Siberut to ask his family to settle in Simatoraimonga. When he left Siberut, many people went along to settle in this place [Simatoraimonga], just as the words of our ancestor said, "Tunung le' kutata'ta' [while illustrating how to hold a spear], abelaat, ka logui-at" [while illustrating how to draw a bow ready to shoot an arrow] (I threw a spear away, thereafter I took a bow and arrow). Our ancestors were tunung, the pioneers who first inhabited this place, and other people were logui who followed our ancestors' trail.

After the arrival of our ancestors, the kin group called the Sakoikoi and others came to inhabit this place [Simatoraimonga]. The kin group called the Taikatubutoinan later occupied the place called Bagat Ureinu. They inhabited an upriver place, claiming the place as their own, but the river mouth, the place where the bamboo had once been planted, belonged to us. The Taikatubutoinan attempted to claim our land. They burned down the bamboo planted by our ancestors. The bamboo was the evidence of our ancestors' occupation of the place. Nowadays, I do not know exactly where our land in Bagat Ureinu is located. I also do not know the borders of the land. What I do know is the names of the land. I know the names of the land because of my ancestral story. If I wanted to become acquainted with my ancestral lands, I would have to refer to the names while asking other people if they know where the lands are located. (Narrated by Gustap Samongilailai, 63 years, Sioban - Sipora, 2004). (See also in Tulius 2012a: 149-156).

The text of pig story told by a storyteller contains some important, historical information of the Samongilailai kin group. The storyteller narrates how his ancestral family settled in Paipajet, instead of Simatalu. However, the family later migrated to Simatalu where the conflict over a pig took place. Marriage between a female member of the Samongilailai and a male member of another kin group in the Simatalu Valley lay at the core of the pig affair. In the pig story, the narrator reveals information about Emeiboblo, who notoriously killed the Sapokka on his own, without any help. Later in the story, the pig storyteller mentioned the places in which his migrating ancestors had lived. The valley of Silaoinan was a famous place among the Samongilailai. There, Samongilailai ancestors received some plots of land. In describing the borders of the plots 
of land, the storyteller mentions other kin groups which were residing in the valley of Silaoinan. This tells us that other kin groups had occupied the area before the Samongilailai arrived there.

The storyteller continued his pig story by recounting information about the situation after the death of his ancestor Emeiboblo. Emeiboblo's descendants became the next leaders in the subsequent course of migrations. Those individuals became prominent within newly established kin groups which used separate names from the Samongilailai.

\section{INTERPRETING THE GENERAL THEMES OF PIG STORIES}

Pig stories describe the migratory movements of Samongilailai ancestors as these forefathers commenced moving out from different places of origin to their current settlements. Emeiboblo is the main actor mentioned in the two stories. Consequently only members of the Samongilailai with the pig story which recounts the story of Emeiboblo and his exploits may presume to be each other's relatives. Other individuals, should they also want to declare themselves members of the Samongilailai, would first have to know the details of the elements featuring the identity of Samongilailai kin group described in the pig story. Even were they to do so, such individuals can simply still be rejected as relatives by the Samongilailai if they do not recollect and retell the elements of the pig story properly. Emeiboblo's descendants are of course acquainted with the common elements of the pig story as it tells about them and their predecessors. The story also provides them with information about their original home, land and gardens. It is a record of the neighbours of the Samongilailai, the path of their migratory movements and relatives who established new kin groups which live in different places.

Besides sharing features of their kin group, every current kin group of which the Samongilailai is composed has its own history of expansion. The change of their kin-names is a clear example. For instance, a few families settled in Bat Koddobat and they became the Sakoddobat; some families dwelled in Bat Lamao and they became the Salamao (Tulius 2012a). Ancestors of these people had also found their land in the course of their migration. Such a piece of land was claimed by only a limited number of members of the kin groups. Therefore, if the ancestors of the Salamao found their particular area of land, other relatives from the Samongilailai could not have a right to this land. Sometimes, a kin group newly established from the Samongilailai acquired some plots of land in the course of their migration. In this case, relatives of the kin group which had emigrated from elsewhere in the Mentawai Islands would not have the same rights to all the land claimed by that kin group unless all the descendants of the pioneering group had died. Relatives of the group which had disappeared would then have the right to claim the plots of land owned by the extinct kin group. Nonetheless, as long as the kin group which claims a plot of land still exists, its relatives only have the right to use the land. Because they are descended from the same ancestral family, they are able to have access to the usufruct of the land of any of the kin groups 
to whom they are related. In a nutshell, people with common Samongilailai ancestry do have a right to cultivate the land of their relatives which have established their own kin groups.

The pig story also informs us about various locations through which the Samongilailai ancestors had passed in the course of their migration. At certain places, each of the separate families established new kin groups and, in their quest for a place to settle, the rest continued their journey in different directions. It might happen that, "After being separated, connections among the separated families were rare, they even might not meet each other at all. Nevertheless, their genealogical ties remain. In a later stage of migratory movements, the migrating families might meet again; however, they did not merge in order to form one kin group like the initial Samongilailai" (Tulius 2012a: 165).

The pig stories reveal that the Samongilailai families have various plots of land. There are two types of collective land in Mentawai owned by a kin group. The first is a plot of land located in the place of origin; the second are plots which were found and claimed in the course of migratory movements. In principle, all these plots of land belong to all Samongilailai descendants (muntogat Samongilailai). The migrating ancestors transferred the protection and maintenance of all communal possessions of the Samongilailai to relatives who did not move away from the plots of land claimed (Tulius 2012a). The pig story also informs us that a younger brother of Emeiboblo named Pabelemanai took care of the Samongilailai property in their homeland.

\section{KINSHIP, MIGRATION, AND LANDOWNERSHIP IN PIG STORIES}

An examination of the pig stories reveals one significant aspect of Mentawai genealogical ideas, namely: the Mentawaians' recollection of their ancestors' names is inconsistent. What one family member remembers about his ancestors is not always the same as what is remembered by other family members. Some people have a strong relationship with their ancestors and maintain the memory of their forefathers by telling stories about them. By counting the ancestors' names in family stories, we can determine how many generations Mentawaians go back in their past. The stories indicate that Mentawai storytellers recollect their ancestors a number of generations. On the evidence from the pig stories, some storytellers remember fewer than eight generations, whereas other storytellers of the same kin group can recollect more than ten generations. A comparison of the order of the names according to family generations shows that the story is also told erratically. An ancestor in a story perceived as a son by one storyteller might be mentioned as a grandfather in the same story told by another storyteller of the same kin group. Nevertheless, when we compare one list of ancestors' names to another list of ancestors' names they do yield several similar names, even though the names are incomplete and counted up inconsistently.

The stories also provide information about migration. As they passed through many places and many generations in the course of their early 
migrations, their lives were full of incident. As illustrated in pig stories, the migration was usually undertaken by several ancestors. Therefore, a list of different names of migrating ancestors is also part and parcel of the content of a family story. A storyteller has to recollect the ancestors' names systematically in order not to forget important events which have affected the family. Different plots of ancestral land are mentioned in the family story, and the place of origin from where the family commenced its expansion and all current related kin groups are recollected accurately.

A migrating group might not remember its relatives in other places, or indeed in the place once occupied by its ancestors. In some cases, migrating families still do have relatives living in those places but, in other cases, no relatives are now left in the place once occupied by its ancestors, as the kin group has moved away from there in its entirety. Unquestionably, ancestors of a kin group have also probably been forgotten if they did not claim any land, establish a new kin group or did not contribute some significant event to the group's history. The upshot is that only some of the prominent ancestors, including those who passed away three to five generations ago, are remembered in Mentawai. It is quite clear that the stories do not report in detail all the events which must have occurred throughout the generations, but instead they record crucial events which are special features of the kin groups which own the stories.

By means of pig stories, Mentawai kin groups like the Samongilailai also remember crucial agreements made by their ancestors in their negotiations with other kin groups, for instance, for land. They also remember important words which serve as evidence that they share a family relationship with other kin groups living in other places on the Mentawai Islands. As oral narratives recall historical matters, they are an important element in the Mentawai oral tradition. Therefore, the general aim of this study is to examine the role of oral narratives in the lives of Mentawaians living in the Mentawai Islands.

Once they had agreed about the borders, it was important to remember their delineation correctly. Furthermore, they had to maintain the borders properly. If the borders were changed on account of a failure to recollect them properly, such a lapse might result in a hostile conflict between two or more groups which share the same borders. When members of a group recollect the place-name of their ancestral land, they might also instantly recollect the kin groups with which their ancestral land shares the same borders. According to custom, a kin group is not allowed to go beyond the borders of their own land in order to seek their daily necessities, unless the landowners of that land have allowed them to do so. Members of other kin groups therefore have to ask permission before extracting natural resources situated on the land of another kin group.

Of its very nature, the pig story also contains historical moments in the life of a particular kin group. In the course of migration, kin groups founded some plots of land. After claiming an area, a kin group would sometimes divide into several families who all migrated to different destinations. At new places, these 
families sometimes found empty (unclaimed) land. Today, many generations later, current members of a kin group might be living in different places and have several plots of (communal) land located in widely separated places. Significantly, Mentawaians give newly claimed places names as a means to maintain the kin group's identity and association with these places. Although related kin groups separated from each other long ago, they often continue to remember who their common ancestors and relatives are and where their relatives are currently living and what their kin group names are. Naturally they also remember where their ancestral lands are located. Information about such matters is currently encapsulated in their family stories.

Abiding by the traditional way of obtaining entitlement to a plot of land, the owner of the story must have a wealth of knowledge about the land, including its location, the ancestor who first found the land, events which connected that land and the names of the kin groups which own neighbouring plots of land. If a kin group can recount these matters convincingly, other kin groups will have little chance to claim the land. The elders of a kin group therefore request the younger generation to remember precisely specific matters like the borders of the land and the ancestor's specific words about the land in order to avoid making a mistake if they have to defend their claim to the land. Storytellers have to preserve their family stories because they contain an enormous amount of essential information. In order to prove their connection with their ancestral land, current members of a kin group try to recollect what their ancestors have told them about neighbouring kin groups when these ancestors still lived in previous places, and to remember the descriptions of the natural surroundings of their ancestral lands. Since there is no written evidence of ancestral land claims, family stories are frequently used as evidence of a claim to a particular plot of land.

Family stories not only provide kin groups with the information necessary to resolve social conflicts, they also precisely define the family relationships existing among related kin groups and their rights to particular plots of land. There are cases of kin groups who are related ancestrally, as they are descended from the same ancestral family, but who nevertheless do not share the same ancestral land because the ancestor who originally found and claimed the land does not happen to be the ancestor who has a direct genealogical link to the other relatives. Only direct descendants of the ancestor have an unequivocal entitlement to such plots of land. Other relatives are allowed to use the land, but must recognize that the land actually belongs to the relatives who are descended from the ancestor who first claimed the land. These matters can be properly arranged without conflict as long as all the kin groups remember the family stories of their ancestral land and their ancestral connections correctly. Therefore, a storyteller has to master all the details of his ancestral property contained in his family stories. By being able to demonstrate their entitlement to particular plot of land, the members of a Mentawai kin group are able to state their existence as the inhabitants of the Mentawai islands. 


\section{MEMORIES OF THE PAST IN PIG STORIES}

The memory of knowledgeable storytellers plays a noteworthy role specifically in winning land disputes and more generally in preserving these important historical accounts. In specific instances, memories of the past are very relevant to solving conflicts. A conflict stirs people's memories of events which happened in the past. A storyteller remembers place-names, ancestors' names, cultural objects, borders of ancestral land, their ancestors' migratory movements and the crucial issues and reasons behind past family conflicts. Stories allow Mentawaians to turn to past events and learn from them in order to cope effectively with their current situation.

However, as said above, the recollection of the content of a family story is not always systematic and consistent. Sometimes, a storyteller can only remember as far back as the names of his great-grandparents. However, another storyteller in the same kin group might recollect seven to ten generations of ancestors. "There are people in many communities across the world who can recite a genealogy or their ancestors back ten generations or more, and yet others who can barely remember their grandparents. This is not because they have a good or bad memory" (Tonkin 1992: 110). In my empirical experience, a storyteller's recollection of past events might be thought not complete if we look only at what the storyteller remembers immediately a researcher asks about historical matters. The storyteller's recollection of the past becomes more structured and more complete when he is given more time to recollect what he has been told.

Mentawaians preserve their historical events by repeatedly telling their stories to younger generations so that the latter will be able to use them when they need to in the future. Bruner (1986:18) argues that stories serve as meaning-generating interpretative devices which frame the present within a hypothetical past and an anticipated future. Pertinently, Mentawaians not only verbalize past happenings in storytelling, they also live with them in their daily activities. For example, when hunting in the forest, an older hunter might remind the younger ones that this is ancestral land of their kin group and tell stories connected to that land. As Tonkin says, "To tell history is to act, but in a verbal mode" (Tonkin 1992: 11). Nonetheless, I agree with Confino who writes, "Not everything is a memory in the same way" (Confino 1997: 1387-8), because people live their lives through historical occurrences and a variety of current realities.

In contrast to remembering, forgetting also plays an important role in Mentawaian oral tradition. Mentawaians sometimes deliberately hide particular events from other people. When this happens, the events can be forgotten. This lapse might be intentional when a storyteller chooses not to give a complete account of how an event occurred. One example of this evasion is the "forgetting" of information about a headhunting raid or an inter-family assault. Mentawaians do not often talk about assaults and headhunting raids which their kin group perpetrated against other kin groups (Schefold 2007). By hiding details of the event, the elders are trying to protect the rest of the 
family from being hunted by the kin groups which were the victims of these raids. As long as the victimized kin group remains unaware of the identity of those who carried out a raid or assault, they will not know on whom to take revenge, and the descendants of the kin group which carried out the raid will be safe. However, if this information becomes known, there is the chance that revenge will be taken. To prevent unpleasantness, storytellers might omit details of raids and assaults carried out by their ancestors. The shadow side of this was that children hear only some of the details of the incident and therefore they might not know how to defend themselves when descendants of the victims come to take revenge. Although the headhunting raid stopped a century ago but it is still remaining some significant consequences to the people at present. Some cases are not closed yet.

In short, Mentawaians do not want to remember particular events if they think these events could have unfortunate consequences for their family members. As just said, this is frequently the case if the storyteller does not want to recollect details of shameful actions or vicious headhunting raids. Another category of information which is often forgotten has to do with ancestors who are not directly related to the creation of a kin group or those who did not contribute to important events in the group. Current generations of kin group remember ancestors from whom they are directly descended, but they often forget details about ancestors who separated from the original kin group and created new kin groups for themselves. It is also not unheard of for some ancestors in the line of direct descent might be forgotten: Mentawaians frequently told me that they do not know the name of the father of one of their prominent ancestors. The long and the short of it is that Mentawaians recollect the names of their ancestors selectively.

The notions of forgetting and remembering discussed by Janet Carsten (1995) and Natalie Zemon Davis and Randolph Starn (1989) resemble the cases I have come across in analysing the pig stories. Mentawaian kin groups deliberately preserve the memory of a significant number of elements of the past because these elements are important to them. Conversely, they simply forget other elements which are insignificant to them. Forgetting and remembering are closely related to social and political intentions. So, to remember or to forget particular historical events has to do with a kin group's political survival strategy. For instance, present landowners do not forget details about their land because the land is their livelihood, their identity and their inheritance from their ancestors.

\section{STORYTELLING IN MENTAWAI}

Nowadays, when notebook and pen have been accepted as part of Mentawaian culture, some Mentawaian families write down the important points of their stories. Relevant items include the names of places which belong to the family, the names of their ancestors who led the family to their current place and particular events which affected the dispersal of the family. Nevertheless, they do not write down the entire contents of their family stories; this is in order 
to protect the story from other kin groups if they should happen to steal the notebook. Particular kin groups even insist on not writing down their family stories so as to ensure the stories are kept secret.

Despite such precautions, a few talented youngsters selected by elders do have an opportunity to learn not only the themes of the story but also the secret words and secret agreements with other kin groups regarding land and other social matters arranged by their ancestors. These young people are adjudged to be more competent to remember the words than other family members if the story is told to them. In fact, a small number of people have a good enough memory to recollect anything in great detail. To tell a story to younger members is to ensure the story is not forgotten. Older people will not be able to keep preserving the story forever. To ensure that the meaning and the complete details of the story are not forgotten, before they die, it is their duty to ensure that selected youngsters will continue this tradition so the following generations will also have the chance to learn these historical accounts. Therefore, the older people who know particular family stories remind the younger generation to pay attention to the family stories. The older people guide the younger generation to the ancestral places and introduce them to the land and plants planted by their ancestors saying, "Remember this land and the trees growing on the land, they belonged to our ancestors and now belong to us. It is our task to take care of them." Older people in Mentawai frequently pass on such messages to younger people.

Unfortunately, despite precautions, a family story does not always remain safely in hands of a kin group. One way in which a family story can spread from one kin group to another is through adoption (sinappit). For various reasons like the death of a child's parents Mentawaians often adopt a child from another kin group. An adopted child is treated like other children in the family and the adopting kin group hopes that the adopted child will remain with his or her new family and keep his or her new identity after adoption. However, the process does not always run smoothly. In some cases, the adopted person later wants to return to his original kin group. He is free to do this, but he is not permitted to take with him anything he acquired while he lived with his adoptive kin group and he will no longer use his adoptive kin-name. While this might be easy with materials objects, he cannot leave behind what he has heard or been told or taught by his adoptive family. If he has heard the family stories of the adoptive group, there is a good chance that he will not have forgotten them and, consequently, when he leave his adoptive family, he carries in his memory the family stories of that group. So, one way or another, the family story of one kin group might end up being told by other kin groups and might even be manipulated for the storyteller's own ends.

Storytellers in Mentawai are customarily male and their numbers are few. They maintain the family story and transmit it to individuals chosen for their seniority, maturity or talent. Adult men have a greater chance of becoming a storyteller than adult women. Talented younger members are usually taught to remember significant points in the family stories and they 
assume the position of storyteller when they become adults. Adult storytellers are seen by the group as reliable, wise persons able to decide on what might and might not be told; worthy guardians of the family stories which are part of the group's identity.

Every storyteller has his particular way of telling a story. A good storyteller is able not only to convey the messages of a story to his listeners; he is also required to do this in an entertaining fashion so that they do not easily get bored and lose their interest in listening to the messages of the past. A storyteller changes his tone of voice at the moment he wants to impart important messages. His gestures enhance the attractiveness of the stories to his audience. In the course of telling their stories, Mentawaian storytellers reproduce ordinary conversations, which they believe to be the words of their ancestors. Sometimes they illustrate how their ancestors acted while accomplishing the particular actions like killing their opponents in a headhunting raid. When they do this, they repeat and imitate the performances of their ancestors, while retelling their ancestors' words. Making certain sounds like beating the wooden floor or wall of their house is meant to attract the serious attention of their listeners. The storytellers sometimes illustrate the contents of their stories by drawing lines or figures on the wooden floor. Or they use particular objects around them to demonstrate what they are telling. Mastering particular techniques in storytelling plays an important role in assisting new storytellers to remember significant contents of stories thoroughly. As this is not done in a day, young storytellers sometimes need to wait for acknowledgement of their position to represent their kin group as the 'real' storytellers. They must first exhibit mature, adult characteristics. Talented young storytellers learn the gestures of the older storytellers when they tell a story. They note how to emphasize the most important words in whole story. They also pay attention to the use of hands when elder storytellers open their arms or use their fingers to articulate the particular importance of the story. Or they learn how to draw plots of their story by making use of other objects around them as they tell their story. A good storyteller is obviously as a good orator.

In the course of the process of learning and, as an individual interpretation develops, various versions of a story might evolve. The appearance of divergent versions of a family story in Mentawai is evidence that storytellers differ in their aptitude to recollect and recount past events. The existence of different versions of a family story also reflects the fact that the storytellers' ability to recollect past events varies. Some storytellers have an excellent memory for recalling details of past events. Other storytellers only remember the general outline of a past event. Particular storytellers focus on telling the entire historical journey of their ancestors. They often remember little more than the place-names and the ultimate destination of the migration. Storytellers with an extensive knowledge and a good memory tell a longer story. They not only remember place-names and the course of the migration, but also know how their ancestors came to possess certain plots of land and 
the verbal agreements made about them. Family stories function as a source of information which can be interpreted in different ways by storytellers and listeners. Members of a kin group consult their family stories to find a resolution to particular social problems as well as to imbibe good social and cultural manners from the stories.

\section{CONCLUSION}

In a nutshell, what do family stories mean to Mentawaians? Undoubtedly, family stories are a source of inspiration which guides them in coping with their current circumstances. The comprehensive knowledge of storytellers of a kin group which is involved in a social conflict over land, for instance will be a great advantage to their kin group in defending their ancestral land from being claimed by other kin groups. In a conflict, a kin group needs prominent storytellers who can accurately remember detailed information about the group's land claims and ancestors I observed that the majority of storytellers are able to recollect eight to twelve generations of ancestors' names, as well as the names of several places through which their ancestors passed during their migration.

Family stories are the verbal form which expresses a Mentawai kin group's identity. A group of family stories is one of the elements which form the identity of a kin group. Storytellers make an effort to remember the details of family stories and the different events of which the stories are composed. The contents of family stories explain a host of matters, including the ancestors of the contemporary Mentawaian kin groups, their places of origins and past family conflicts. Family stories also describe the migratory movements of these ancestors, as they commenced moving out of their different places of origin to their current settlements. Other elements are plots of ancestral land and genealogical ties which the kin group shares with other kin groups. Finally, Mentawai family stories represent the high potential of human consciousness. Family stories in Mentawai reflect contemporary people's memory of the past and also fulfil their political needs when faced with the current changes in Mentawai by helping them decide which of the kin groups share genealogical bonds and ancestral land. Mentawaian kin groups highly appreciate their family stories as a key element in their identity.

\section{REFERENCES}

Bauman, Richard. 1986. Story, performance, and event; Contextual studies of oral narrative. Cambridge [etc.]: Cambridge University Press.

Basso, Keith H. 1996. Wisdom sits in places; Landscape and language among the Western Apache. Albuquerque: University of New Mexico Press.

Bernard, H.R. 1994. Research methods in anthropology; Qualitative and quantitative approaches. London: Sage Publications.

Briggs, Charles L. 1986. Learning how to ask; A sociolinguistic appraisal of the role of the interview in social science research. Cambridge: Cambridge University Press. 
Bruner, Edward M. 1986. "Experience and its expressions", in: Victor W. Turner and Edward M. Bruner (eds), The anthropology of experience, pp. 3-30. Urbana and Chicago: University of Illinois Press.

Carsten, Janet. 1995. "The politics of forgetting; Migration, kinship, and memory on the periphery of the Southeast Asian state", Journal of the Royal Anthropological Institute 1(2): 317-335.

Confino, Alon. 1997. "Collective memory and cultural history; Problems of method", The American Historical Review 102(5): 1386-1403.

Coser, Lewis A. 1992. “Introduction; Maurice Halbwachs 1877-1945”, in: Maurice Halbwachs, On collective memory; Edited, translated, and with an introduction by Lewis A. Coser, pp. 1-34. Chicago: The University of Chicago Press.

Davis, Natalie Zemon and Randolph Starn. 1989. "Introduction”, Representations 26: 1-6.

Darmanto and Abidah B. Setyowati. 2013. Berebut Hutan Siberut; Orang Mentawai, kekuasaan, dan politik ekologi. Jakarta: Kepustakaan Populer Gramedia.

Feld, Steven and Keith H. Basso (eds). 1996. Sense of place. Santa Fe, NM: School of American Research.

Fentress, James and Christopher J. Wickham. 1992. Social memory; New perspectives on the past. Oxford: Blackwell.

Finnegan, Ruth. 1992. Oral traditions and the verbal arts; A guide to research practices. London and New York: Routledge.

Fox, James J. 1980. "Retelling the past; the communicative structure of a Rotinese historical narrative", Canberra Anthropology 3(1): 56-66.

Geertz, Hildred and Clifford Geertz. 1964. “Teknonymy in Bali; Parenthood, age-grading, and genealogical amnesia", Journal of the Royal Anthropological Institute of Great Britain and Ireland 94(2): 94-108.

Halbwachs, Maurice. 1992. On collective memory; Edited, translated, and with an introduction by Lewis A. Coser. Chicago: The University of Chicago Press. [Translated from Les cadres sociaux de la mémoire, published by Presses Universitaires de France, Paris, 1952.]

Hoskins, Janet. 1998. Biographical object; How things tell the story of people's lives. London and New York: Routledge.

Loeb, Edwin M. 1928. "Mentawei social organization”, American Anthropologist 30: 408-433.

Nooy-Palm, Hetty. 1968. "The culture of the Pagai-islands and Sipora, Mentawai", Tropical Man 1: 152-238.

Persoon, Gerard A. 2003. "Conflicts over trees and waves on Siberut Island", Geografiska Annaler 85B(4): 253-264.

Persoon, Gerard and Reimar Schefold. 1985. Pulau Siberut; Pembangunan sosialekonomi, kebudayaan traditional, dan lingkungan hidup. Jakarta: Penerbit Bhratara Karya Aksara.

Rubin, David C. 1995. Memory in oral traditions; The cognitive psychology of epic, ballads, and counting-out rhymes. New York: Oxford University Press. 
Schefold, Reimar. 1973. "Religious conceptions on Siberut, Mentawai", Sumatra Research Bulletin (Berita Kajian Sumatera) II(2): 12-24.

Schefold, Reimar. 1988. Lia; Das grosse Ritual auf den Mentawai-Inseln (Indonesien). Berlin: Dietrich Reimer.

Schefold, Reimar. 1991. Mainan bagi roh; Kebudayaan Mentawai. Jakarta: Balai Pustaka.

Schefold, Reimar. 2007. "Ambivalent blessings; Headhunting on Siberut (Mentawai) in a comparative Southeast Asian perspective", Anthropos 102: 479-494.

Steedly, Mary Margaret. 1993. Hanging without a rope; Narrative experience in colonial and postcolonial Karo land. Princeton, NJ: Princeton University Press.

Thompson, Paul. 2000. The voice of the past; Oral history. Third edition. New York: Oxford University Press.

Tonkin, Elizabeth. 1992. Narrating our pasts; The social construction of oral history. Cambridge: Cambridge University Press.

Tulius, Juniator. 2012a. Family stories; Oral tradition, memories of the past, and contemporary conflicts over land in Mentawai, Indonesia. Unpublished PhD Thesis, Leiden University. [This thesis can also be accessed online on: https://openaccess.leidenuniv.nl/handle/1887/20262.]

Tulius, Juniator. 2012b. "Stranded people; mythical narratives about the first inhabitants of Mentawai Islands", Wacana, Journal of the Humanities of Indonesia 14/2: 215-240.

Tulius, Juniator. 2014. "PhD thesis summary. Family stories; Oral tradition, memories of the past, and contemporary conflicts over land in Mentawai, Indonesia", Wacana, Journal of the Humanities of Indonesia 15/1: 190-200.

Vansina, Jan. 1973. Oral tradition; A study in historical methodology. [Translated from De la tradition Orale; Essai de Méthode Historique, 1961 by H. M. Wright]. Middlesex: Penguin University Books.

Wawman, Richard Charles. 1999. "House of the spirits". [An Essential TV/ Videal Production for the Discovery Channel.] 